\title{
Petrografia e geoquímica das rochas vulcânicas do Grupo Roosevelt, província ígnea Teles Pires, SW do Cráton Amazônico
}

\author{
Maria Elisa Fróes Batata ${ }^{1}$ Jayme Alfredo Dexheimer Leite ${ }^{I}$ \& Maria Zélia Aguiar de Sousa
}

\begin{abstract}
Resumo A Província Ígnea Teles Pires (PITP), com cerca de $40.000 \mathrm{~km}^{2}$ de extensão, localiza-se na porção sudoeste do Cráton Amazônico, norte de Mato Grosso, sendo constituída por rochas vulcânicas bimodais e rochas graníticas cogenéticas de idades entre 1.8-1.75 Ga. Na região dos municípios de Juína, Castanheira e Juruena, os vulcanitos ácidos dessa província foram estudados e classificados como ignimbritos, representados por tufos suportados por matriz cinerítica, tufos suportados por cristais e tufos estratificados. Por vezes, mostram evidências de alteração hidrotermal, como resultado de provável interação com água do mar, ou de milonitização e/ou metamorfismo de fácies xisto-verde. O magmatismo que originou essas rochas possui composição não expandida, variando de dacítico a riolítico, caráter cálcio-alcalino do tipo I, tendo evoluído de metaluminoso a levemente peraluminoso e sido gerado com moderada $\mathrm{fO}_{2}$. Os resultados aqui obtidos, associados à idade em torno de 1,76 Ga, permitem a correlação desses litotipos com a unidade estratigráfica Grupo Roosevelt.
\end{abstract}

Palavras-chave: Cráton Amazônico, vulcanismo ácido, petrografia, geoquímica.

\begin{abstract}
Petrography and geochemistry of the volcanic rocks of the Roosevelt Group - Teles Pires Igneous Province, SW Amazonian Craton. The Teles Pires Igneous Province (PITP), covers an area of ca. 40.000 square kilometers, and is situated in the southwestern portion of the Amazonian Craton, north of Mato Grosso state, consisting of 1,8-1,75 Ga old bimodal volcanics rocks and associated cogenetic granitic rocks. On the Juína, Castanheira and Juruena regions, the acid volcanits have been studied and classified as ignimbrite, represented for matrix cineritic supported tuff, crystal supported tuff and stratified tuff. Locally, these rocks display evidence of hydrothermal alteration, as a result of probable interaction with seawater, mylonitization and/or green-schist facies metamorphism. The magmatism that originated these studied rocks is dacitic to riolitic and do not define an expanded series, and is characterized as calc-alkaline of I type. It evolved from of metaluminous to slightly peraluminous. It was generated at moderate $\mathrm{fO} 2$. The obtained results associated with the age of around 1,76 Ga, allow the correlation of these volcanic rocks with Roosevelt Group.
\end{abstract}

Keywords: Amazonian Craton, acid volcanism, geochemistry, petrography.

INTRODUÇÃO A Província Ígnea Teles Pires - PITP (Leite et al. 2001a) situa-se na porção sudoeste do Cráton Amazônico, e suas ocorrências extrapolam os limites das províncias geocronológicas Ventuari-Tapajós e Rio Negro-Juruena (Tassinari et al. 1996; Tassinari \& Macambira 2000) ou Tapajós-Parima e Rondônia-Juruena (Santos et al. 2000). As unidades que a constituem ocorrem numa faixa de $350 \mathrm{~km}$ de comprimento de direção aproximada E-W, aflorando principalmente ao longo do rio homônimo, mas também nas cercanias das cidades de Colíder, Nova Canaã do Norte, na borda norte do Graben do Caiabis e nos arredores dos municípios de Juruena e Aripuanã. Constitui-se de grande volume de rochas efusivas e vulcanoclásticas essencialmente ácidas, com termos básicos subordinados e rochas graníticas cogenéticas. Os vulcanitos ácidos que ocorrem nas proximidades de Juína, Castanheira e Juruena (Fig. 1), constituem o objeto desta pesquisa e foram estudados do ponto de vista petrográfico e geoquímico a partir de 35 seções delgadas e igual número de amostras para análises químicas.
CONTEXTO GEOLÓGICO REGIONAL A estratigrafia sugerida para a região é representada por dez unidades, da mais antiga para a mais jovem: Terreno Granítico Alta Floresta, Complexo Tabaporã, Tonalito Japuíra, Grupo Roosevelt, Granito Zé do Torno, Suíte Rio do Sangue, Suíte Intrusiva Tatuí, Granito Aripuanã, Formação Dardanelos (Grupo Caiabis), e Grupo Parecis pertencente às Coberturas Sedimentares Fanerozóicas (Fig. 2A-B), descritas a seguir.

O Terreno Granítico Alta Floresta (Leite et al. 2001b) constitui-se de rochas deformadas, anteriormente incluídas no Complexo Xingu, situadas na porção E-NE da Folha SC-21 Juruena, que ocorrem entre os municípios de Peixoto de Azevedo e Juruena. É formado por diversas suítes de natureza cálcio-alcalina e composições variando desde dioríticas até graníticas, intrusivas em gnaisses polideformados correlacionáveis ao Complexo Cuiú-Cuiú da Província Tapajós (Lacerda Filho et al. 2001). O padrão geocronológico destas suítes mostra intervalo temporal de aproximadamente $100 \mathrm{Ma}$, entre $1,89 \mathrm{Ga}$ e 1,79 Ga, com idades modelo

1- Programa de Pós-Graduação, Universidade Federal de Mato Grosso, Cuiabá (MT), Brasil. E-mail: mefroes@terra.com.br, jayme.a.leite@gmail.com,mzaguiar@terra.com.br 


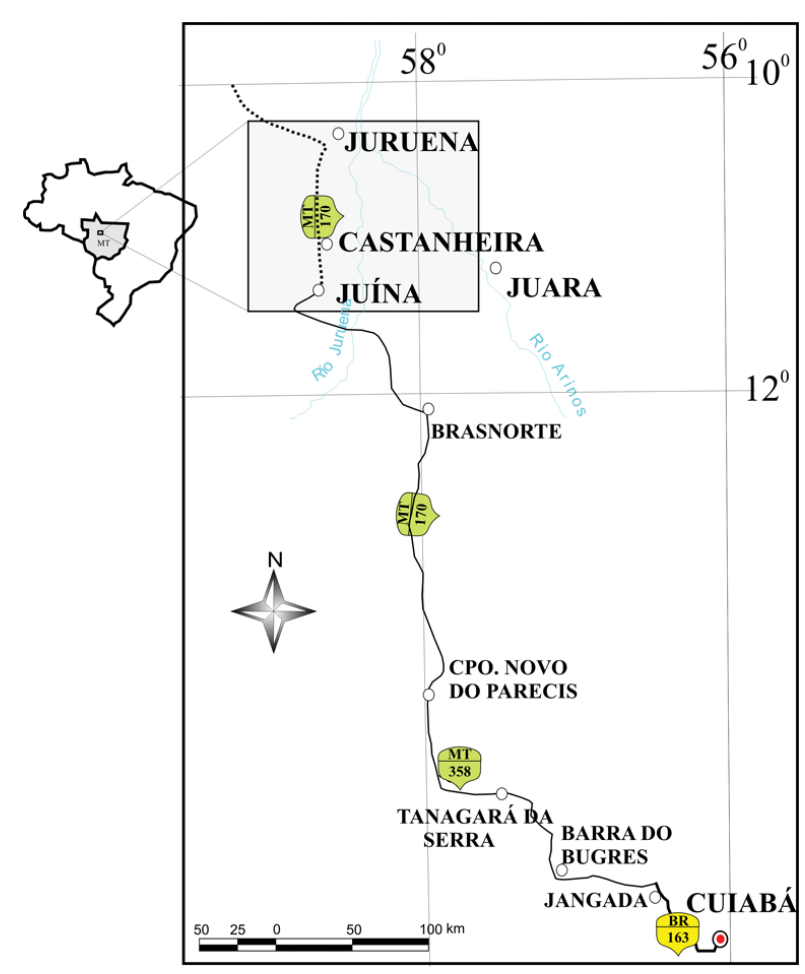

Figura 1 - Mapa de localização da área de estudo.

Sm-Nd entre 2,35 Ga e 2,22 Ga.

O Complexo Tabaporã aflora nas proximidades do município homônimo e ao longo do curso médio do rio Arinos, a sudoeste da cidade de Juara. Seus litotipos apresentam granulação grossa a média, cor cinza a preta, com bandamento gnáissico de direção preferencial E-W e mergulhos de moderados a altos para N. As rochas desta unidade consistem de quartzo dioritos, granodioritos e monzogranitos, metamorfizadas na fácies anfibolito superior a granulito, apresentando uma foliação milonítica de direção NNW e mergulhos de ângulo variável para NNE, com idades entre 1,70 a 1,77 Ga.

O Tonalito Japuíra estende-se desde o Rio Arinos no noroeste de Juara, cruzando o Rio Juruena na reserva indígena homônima, até Aripuanã. Essa unidade compõe-se de rochas cinza a cinza-esbranquiçadas, de granulação grossa a média, e seus litotipos apresentam foliação metamórfica proeminente, algumas vezes transicionando para bandamento gnáissico com direções preferenciais NW-SE e E-W. Petrograficamente classificam-se como tonalitos, com restrita variação para granodioritos, com idade $\mathrm{Pb}-\mathrm{Pb}$ em zircão de $1,77 \mathrm{Ga}$ e $\mathrm{T}_{(\mathrm{DM})}$ em torno de 2,26 e $\xi_{\mathrm{Nd}}(1.77)$ levemente negativo (Leite et al. 2006).

O Granito Zé do Torno corresponde a corpos distribuídos concordantemente com a estruturação regional, em faixas alongadas e descontínuas entre os municípios de Juruena e Aripuanã (MT), ora apresentando-se como enclaves nas rochas vulcânicas do Grupo Roosevelt. Estes litotipos variam de equigranulares médios a porfiríticos de matriz fina a média, com cores de rosa a cinza e geralmente exibem textura rapakivi
(Lacerda Filho et al. 2004), sendo classificados como sieno a monzogranitos, com idade de $1.755 \pm 5 \mathrm{Ma}$ obtida pela metodologia U-Pb em zircão por SHRIMP (Néder et al. 2001).

O Grupo Roosevelt expõe-se principalmente ao longo do vale do Rio Teles Pires, na divisa entre os estados de Mato Grosso e Pará, desde a região da Serra Formosa até o Município de Aripuanã, com ocorrências importantes nas cercanias dos municípios de Colíder e Nova Canaã do Norte, ao longo do Rio dos Peixes e ao sul do Graben dos Caiabis. Constitui-se por rochas vulcânicas ácidas, e, mais raramente, diques e sills básicos, com uma granitogênese associada. Os termos ácidos têm composicição dacítica a riolítica, enquanto a porção básica é representada por termos toleíticos, caracterizando vulcanismo bimodal, de natureza continental (Leite \& Saes 2000, Néder et al. 2000). Quanto à granitogênese associada, consiste em rochas avermelhadas, isotrópicas, com composição dominantemente monzo a sienogranítica, com raros riebeckita granitos. Os dados geocronológicos $\mathrm{Pb}-\mathrm{Pb}$ e U-Pb em zircão para as rochas intrusivas (Néder et al. 2000, Leite et al. 2001a, Santos et al. 2001, Pinho et al. 2003) indicam uma variação entre $1,801 \mathrm{Ga}$ e $1,759 \mathrm{Ga}$, semelhantes àqueles obtidos para a porção vulcânica da unidade, sugerindo contemporaneidade entre os dois processos, o que já havia sido proposto por Basei (1977) e Tassinari et al. (1984).

A Suíte Rio do Sangue apresenta-se sob a forma de um cinturão alongado de direção $\mathrm{E}-\mathrm{W}$, que se estende desde as proximidades de Tabaporã até as cercanias do município de Juína ao longo da qual se observam zonas de cisalhamento de direção E-W a WNWESE, distribuídas de forma heterogênea. Compõe-se por cinco unidades: Granito Fontanillas, Granito Juara, Charnockito-Mangerito São Roque, Gabro Juína e por termo anortosítico identificado, até o momento, em afloramento restrito na localidade de Castanheiras. Suas rochas variam de sieno a monzogranitos e raros granodioritos rosa e vermelho, de equi a inequigranulares finos a porfiríticos, e, subordinadamente, gabros, dioritos e diabásio de cores cinza a preto, granulação média a fina, bem como anortosito melanocrático de cor cinza a cinza-esbranquiçado, inequigranular médio a grosso, com textura cumulática, constituído por até $90 \%$ de cristais tabulares subédricos a anédricos de plagioclásio (bytownita) e 10\% de máficos.

O Granito Aripuanã ocorre nas proximidades do município homônimo, no sul do Distrito de Filadélfia até o nordeste do Município de Castanheira. Constitui-se dominantemente por sienogranitos isotrópicos cinza e cinza-esbranquiçados, e vermelhos quando oxidados, equigranulares grossos a porfiríticos, com megafenocristais equidimensionais de feldspato alcalino pertítico, por vezes rapakivi, fenocristais menores de plagioclásio e, mais raramente, de quartzo, imersos em matriz equigranular média. Os dados geocronológicos indicam idades de cristalização de $1537 \pm 07$ Ma e 1546 $\pm 05 \mathrm{Ma}$ (Rizzotto et al. 2002).

As coberturas sedimentares descritas na área de estudo estão representadas pela Formação Dardanelos 

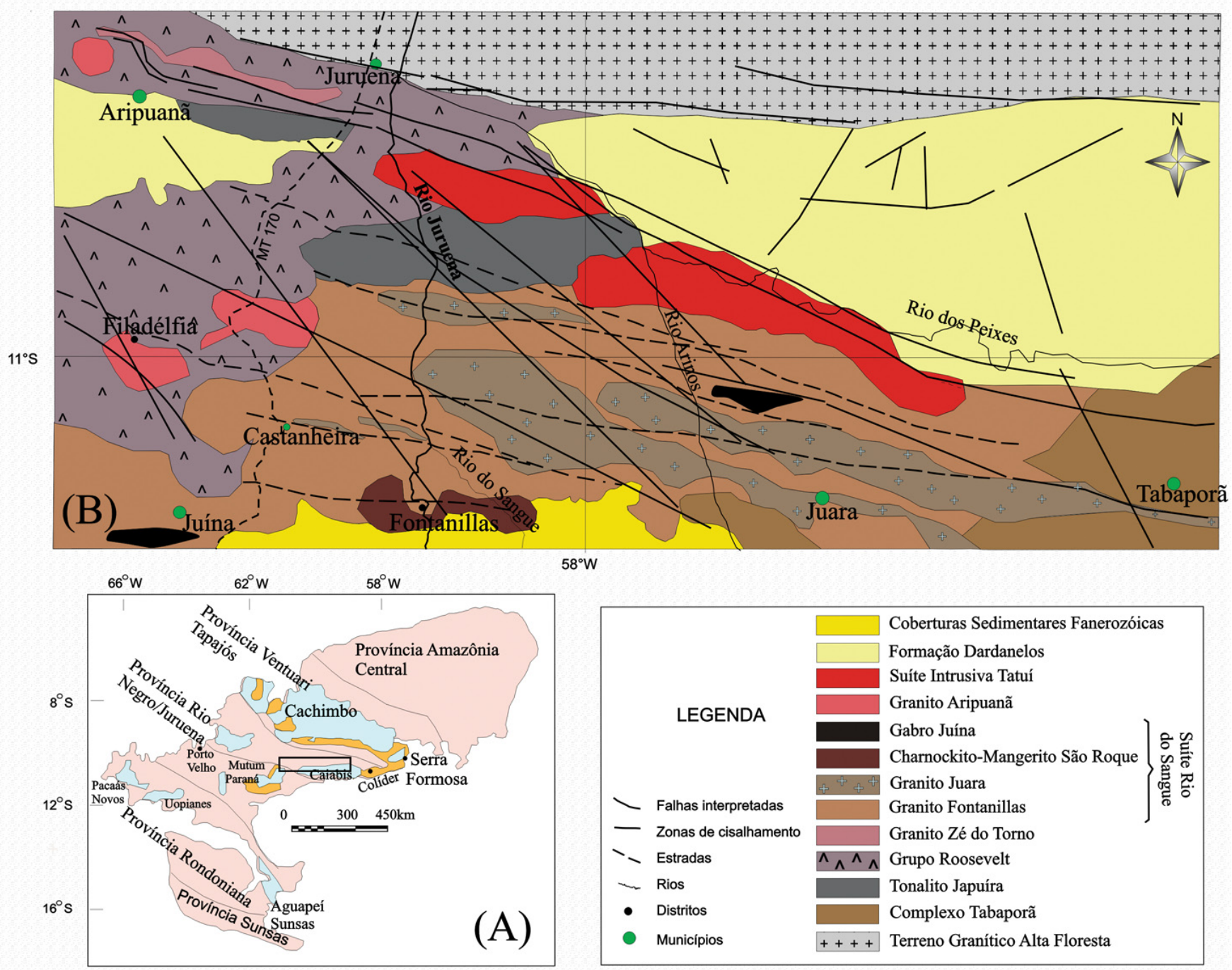

Figura 2 - Mapas: (A) de localização da Folha SC-21 Juruena no contexto do Cráton Amazônico (Províncias segundo Tassinari et al. 1996; Tassinari \& Macambira 2000); (B) geológico de parte da Folha SC-21 Juruena (Batata 2007, modificado de Leite et al. 2005).

(Grupo Caiabis), e por coberturas sedimentares fanerozóicas da Bacia do Parecis. A primeira delas está condicionada à estrutura denominada Gráben do Caiabis, ao sul do Gráben do Cachimbo, com idade máxima para início de sua deposição considerada como $1,3 \mathrm{Ga}$ (Leite \& Saes 2003). As coberturas fanerozóicas ocorrem ao sul da PITP e incluem em superfície uma grande extensão de depósitos arenosos do Mesozóico e do Cenozóico.

PETROGRAFIA Do ponto de vista petrográfico, as rochas sob enfoque são caracterizadas por uma variação composicional restrita, dacítica a riolítica, sendo classificadas geneticamente como ignimbritos, podendo ser individualizados: tufos suportados por matriz cinerítica, tufos suportados por cristais e tufos estratificados, todos levemente magnéticos. Exibem estrutura maciça e, subordinadamente, estratificada, com granulação variando de cinza fina até lapilli e cores cinza-escuro a cinza-esbranquiçado, a avermelhada quando fortemente argilizados/oxidados. A deformação e metamorfismo ocorrem de modo não penetrativo e, quando presentes, as rochas mostram-se milonitizadas e/ou com minerais estirados marcando uma foliação. Microscopicamente apresentam textura porfirítica a glomeroporfirítica e, localmente, eutaxítica, perlítica e micrográfica. São comuns cristaloclastos, púmices, fiammes, fragmentos líticos, shards, bem como níveis ricos em amígdalas arredondadas e/ou coalescentes. A matriz é tufácea formada por frações de tamanho pó $(<1 / 16 \mathrm{~mm})$ a cinza $(1 / 16$ a $2 \mathrm{~mm}$ ), que às vezes se intercalam produzindo tufos estratificados. Observam-se produtos de devitrificação nessa mesóstase, nos púmices e nos litoclastos.

Os púmices exibem contornos bem definidos (Figs. 3A, 4A e 4C), sendo arredondados, elipsoidais ou estirados, ou ainda apresentando-se coalescentes em rochas com maior grau de soldamento. Mostram-se geralmente recristalizados, compostos por arranjos de feldspato alcalino e quartzo, às vezes, em intercrescimento micrográfico. Os fiammes, freqüentemente estirados e orientados, definindo uma foliação, são comuns 

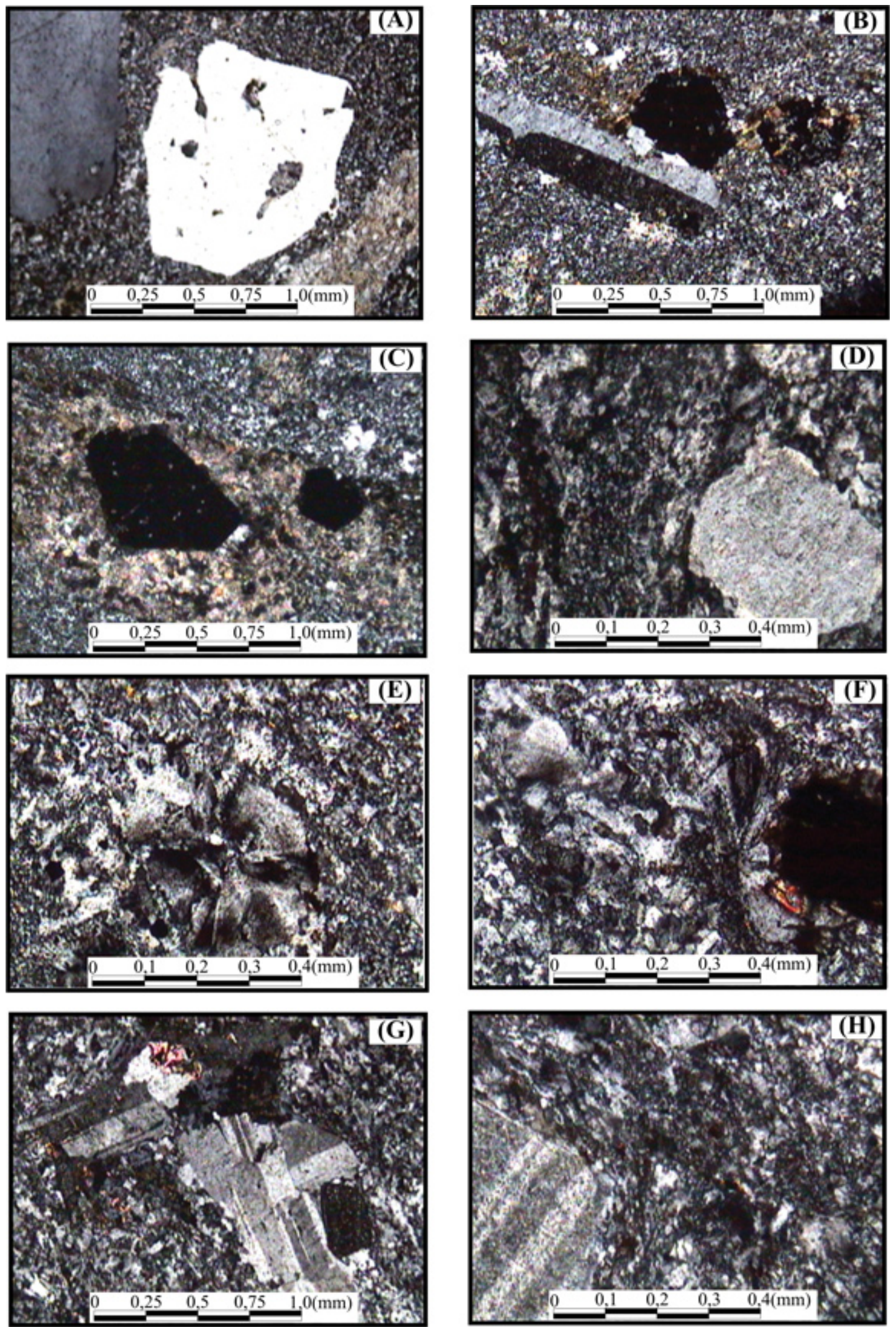

Figura 3 - Fotomicrografias ilustrando: (A) Cristaloclasto de quartzo com bordas e golfos de corrosão, e púmice elipsoidal; (B) Cristaloclasto de sanidina e litoclasto acidental com granada; (C) Litoclasto acidental com cristais euédricos de granada, mostrando contato nítido com a matriz; (D) Fiammes e textura eutaxítica contornando cristaloclasto euédrico; (E) Elementos de devitrificação em altas temperaturas - detalhe de esferulito; $(F)$ Esferulito do tipo gravataborboleta, opaco e zircão; (G) Textura glomeroporfiritica constituida por cristaloclastos de plagioclásio associados a clorita secundária; $(H)$ Detalhe de textura eutaxítica contornando cristal de plagioclásio. Imagens com polarizadores cruzados. 
e identificados por formas achatadas e alongadas e cores escuras; constituem comumente um arranjo eutaxítico que contorna os cristaloclastos (Figs. 3D e 3H). Os litoclastos, arredondados ou angulosos e alongados, encontram-se em algumas amostras e geralmente têm dimensões maiores que os púmices. Podem representar termos cognatos de composição similar à mesóstase ou fragmentos acidentais de rochas de possível origem pelítica, onde se observam além dos argilo-minerais, grãos de epidoto e titanita e cristais euédricos a arredondados de granada (Figs. 3B e 3C). Os produtos de devitrificação envolvendo nucleação e intercrescimento de cristalitos fibrosos de feldspato alcalino e de polimorfos de sílica (originados, possivelmente, de cristobalita ou tridimita) estão representados por esferulitos do tipo gravata borboleta (Fig. 3F), axiolito e, principalmente, esférico, que corresponde a estruturas circulares ou concreções radiadas coalescentes entre si (Fig. 3E). Nas porções internas dos esferulitos encontram-se, às vezes, pequenas cavidades na forma de estrelas, vugs, geradas pela liberação dos gases formados quando da saturação do líquido magmático. Às vezes, os esferulitos evoluem para um arranjo de cristais submilimétricos intercrescidos, formando textura microgranofírica.

Estas rochas caracterizam-se, em geral, pela grande proporção de fragmentos de cristais e porfiroclastos, ocasionalmente poiquilíticos, de quartzo, plagioclásio e feldspato alcalino, freqüentemente embaiados e com golfos de corrosão. Foram identificados também porfiroclastos de anfibólio e pseudomorfos de plagioclásio constituídos por epidoto, quartzo e clorita, numa matriz essencialmente quartzo-feldspática, tendo biotita como principal máfico e anfibólio subordinado. Os minerais secundários provenientes de alteração estão representados por argilo-minerais, epidoto/clinozoizita, clorita, sericita, muscovita, calcita, esfalerita e opacos, e os minerais acessórios primários por grande quantidade de titanita, allanita metamictizada, zircão, apatita, rutilo e opacos.

O plagioclásio possui composição de albita a oligoclásio e, subordinadamente, andesina; ocorre na matriz ou em fenocristais euédricos a subédricos, podendo constituir glômeros (Fig. 3G) e apresentar zonação dos tipos normal ou oscilatório. Exibe principalmente hábito tabular e mostra-se encurvado devido à sobrecarga quando ainda em condições plásticas. São comuns geminações albita, periclina e albita+periclina combinadas, que podem ocorrer bem preservadas ou apenas como vestígios, devido aos intensos processos de alteração hidrotermal, que incluem sericitização, saussuritização ou argilização. Em algumas amostras encontra-se completamente pseudomorfisado por epidoto esverdeado associado a clorita e quartzo (Fig. 4D). Nas rochas milonitizadas forma porfiroblastos com bordas cominuídas ou lamelas deformadas. O feldspato alcalino corresponde, provavelmente, ao ortoclásio e/ou microclínio, comumente pertítico, e se apresenta em cristaloclastos tabulares subédricos a anédricos de dimensões menores do que o plagioclásio, em geral mostrando geminações Carlsbad e/ou combinadas albita+periclina, corrosão nas bordas e intensa sericitização e argilização. Freqüentemente apresenta-se intercrescido com minerais polimorfos de sílica constituindo as texturas micrográficas ou esferulíticas da matriz ou dos púmices e litoclastos. O feldspato potássico de alta temperatura, a sanidina (Fig. 3B), é também identificada em algumas amostras, por suas propriedades ópticas.

O quartzo ocorre em porfiroclastos euédricos a subédricos, por vezes com a forma hexagonal típica de polimorfos de sílica de alta temperatura ainda preservada, embora geralmente ocorram embaiados e com golfos preenchidos pela matriz, evidenciando intensa corrosão (Fig. 3A). Participa também da mesóstase em minúsculos cristais, ou como produto de devitrificação com hábito fibroso a fibro-radiado e vermicular.

A biotita ocorre em minúsculas palhetas disseminadas pela matriz ou em plaquetas formando agregados juntamente com clorita, epidoto, vidro e zircão, que nela forma halos pleocróicos; outras vezes aparece como sombra de pressão nas bordas dos fenocristais de feldspato. É comum representar uma fase primária e, mais raramente, ocorrer como produto secundário, constituindo faixas lepidoblásticas nas rochas milonitizadas (Fig. 4B). A hornblenda é uma fase rara, encontrada em poucos litotipos e apresenta-se parcial a totalmente substituída por biotita e clorita, ocorrendo por vezes como pseudomorfo. O epidoto é comum e representa fase primária ou de alteração; O primeiro tipo ocorre em cristais euédricos prismáticos bem desenvolvidos, às vezes zonados ou com núcleo de allanita, tanto dispersos na mesóstase quanto formando agregados com biotita e quartzo; Como produto secundário, apresentase em grãos anédricos dispersos ou associados à clorita, quartzo e opacos, preenchendo fraturas ou pseudomorfisando fenocristais de plagioclásio (Fig. 4D).

GEOQUÍMICA As análises químicas foram realizadas pelo Laboratório Acmelab, Ontário - Canadá, por ICP-MS e ICP-ES, para elementos maiores, menores, traços e terras raras, e os resultados estão apresentados nas tabelas 1 a 3. Com base nos dados obtidos, buscou-se a caracterização geoquímica, a definição da natureza do magmatismo e possíveis indicações sobre a ambiência tectônica das rochas estudadas da PITP. Excetuando-se uma única amostra de composição basáltica, os diferentes litotipos revelaram, independente do tipo faciológico, natureza ácida, com uma relativa homogeneidade composicional e valores de $\mathrm{SiO}_{2}$ variando entre 63 e $76 \%$.

Utilizando-se o diagrama de discriminação de processos de alteração, $\mathrm{Al}_{2} \mathrm{O}_{3}$ versus $\mathrm{TiO}_{2}$, proposto por Cattalani \& Bambic (1994, in: Leite et al. 2005), a maioria dos pontos que representam as rochas estudadas corresponde à composição dacítica a riolítica e posiciona-se próxima ao trend de fracionamento, sugerindo incipiente estágio de alteração em relação aos elementos considerados (Fig. 5). As análises correspondentes à rocha básica (ME25-B) e às amostras FET8-A, FET12-Z e ME7 mesmo sem evidenciar neste diagrama perda ou ganho expressivo de massa, apresentam resultados discrepantes para $\mathrm{CaO}, \mathrm{Na}_{2} \mathrm{O}$ e $\mathrm{K}_{2} \mathrm{O}$ (Tab. 1), 

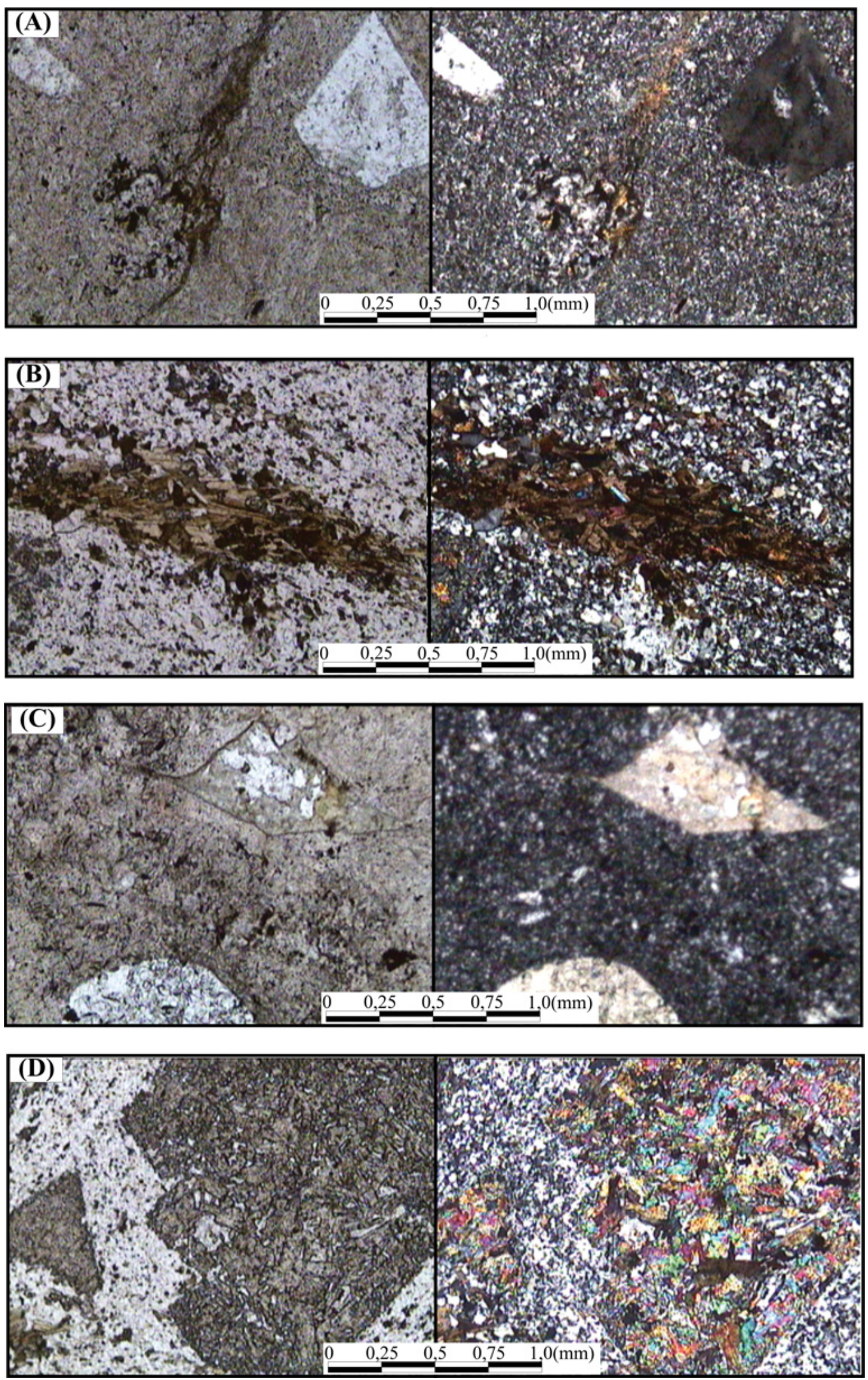

Figura 4 - Fotomicrografias ilustrando: (A) Fragmentos de cristal pontiagudo com corrosão magmática, e púmice arredondado, em matriz tufácea; fraturamento preenchido por epidoto e clorita; (B) Parte de nível máfico da foliação milonítica formado por agregado de palhetas orientadas de biotita, evidenciando deformação; (C) Shard em plate devitrificada, com neoformação de calcita+quartzo+clorita, e púmice elipsoidal amoldado a anteparo de cristaloclasto; (D) Pseudomorfose total, principalmente para grãos de epidoto, de fenocristal de plagioclásio fragmentado. Imagens com polarizadores paralelos e cruzados, à esquerda e direita, respectivamente. 
Tabela 1 - Composição química de elementos maiores e menores dos vulcanitos estudados.

\begin{tabular}{|c|c|c|c|c|c|c|c|c|c|c|c|c|}
\hline Elementos & $\mathrm{SiO}_{2}$ & $\mathrm{TiO}_{2}$ & $\mathrm{Al}_{2} \mathrm{O}_{3}$ & $\mathrm{Fe}_{2} \mathrm{O}_{3}$ & $\mathrm{MnO}$ & $\mathrm{MgO}$ & $\mathrm{CaO}$ & $\mathrm{Na}_{2} \mathrm{O}$ & $\mathrm{K}_{2} \mathrm{O}$ & $\mathrm{P}_{2} \mathrm{O}_{5}$ & LOI & Total \\
\hline Amostras & $\%$ & $\%$ & $\%$ & $\%$ & $\%$ & $\%$ & $\%$ & $\%$ & $\%$ & $\%$ & $\%$ & $\%$ \\
\hline \multicolumn{13}{|l|}{ Basáltica } \\
\hline ME 25.B & 52,3 & 0,89 & 17,53 & 9,89 & 0,2 & 4,26 & 8,55 & 2,58 & 1,78 & 0,28 & 0.6 & 98,86 \\
\hline \multicolumn{13}{|l|}{ Dacíticas } \\
\hline FET 08.A & 62,58 & 0,38 & 10,34 & 6,3 & 0,52 & 5,46 & 8,47 & 0,18 & 5,28 & 0,1 & 0.3 & 99.91 \\
\hline ME 93 & 62,68 & 0,63 & 16,26 & 5,99 & 0,09 & 2 & 5,9 & 3,2 & 2,17 & 0,17 & 0.8 & 99,89 \\
\hline ME 92 & 63,31 & 0,65 & 16,11 & 5,83 & 0,09 & 2,04 & 4,58 & 3,3 & 3,09 & 0,18 & 0.8 & 99,98 \\
\hline ME 13.A & 66,55 & 0,51 & 16,17 & 3,76 & 0,08 & 0,97 & 3,37 & 3,6 & 3,89 & 0,14 & 1.1 & 100,14 \\
\hline ME 33.B & 66,72 & 0,68 & 14,5 & 5,15 & 0,1 & 1,33 & 3,41 & 2,96 & 4,22 & 0,19 & 0.8 & 100,06 \\
\hline ME 42 & 75,41 & 0,15 & 13,2 & 1,47 & 0,15 & 0,13 & 1,41 & 4,33 & 3,64 & 0,04 & 0.6 & 100,53 \\
\hline ME 41 & 76,01 & 0,33 & 12,09 & 2,44 & 0,06 & 0,38 & 2,04 & 3,62 & 2,47 & 0,08 & 0.9 & 100,42 \\
\hline \multicolumn{13}{|l|}{ Riolíticas } \\
\hline ME 32.B & 66,7 & 0,71 & 14,7 & 5,58 & 0,06 & 0,52 & 2,51 & 2,71 & 5,7 & 0,19 & 1 & 100,38 \\
\hline ME 20.C & 66,94 & 0,68 & 14,96 & 4,89 & 0,03 & 1,14 & 2,49 & 4,27 & 3,59 & 0,23 & 0.8 & 100,02 \\
\hline ME 12.A & 67,43 & 0,5 & 15,63 & 3,78 & 0,1 & 0,94 & 3,21 & 4,08 & 3,84 & 0,14 & 0.5 & 99,61 \\
\hline ME 11 & 67,53 & 0,47 & 15,9 & 3,61 & 0,06 & 0,91 & 2,85 & 3,58 & 4,04 & 0,11 & 1.1 & 100,16 \\
\hline ME 96 & 67,65 & 0,45 & 16,81 & 2,83 & 0,1 & 0,76 & 1,62 & 5 & 4,06 & 0,1 & 1 & 100,38 \\
\hline ME 19 & 68,07 & 0,5 & 14,44 & 3,9 & 0,06 & 0,51 & 2,79 & 3,65 & 4,46 & 0,14 & 1.7 & 100,22 \\
\hline ME 32.A & 68,16 & 0,69 & 13,93 & 4,93 & 0,05 & 0,92 & 2,29 & 2,28 & 5,7 & 0,19 & 0.5 & 99,19 \\
\hline ME 06.A & 68,48 & 0,5 & 14,75 & 3,15 & 0,18 & 0,56 & 2,87 & 3,6 & 4,6 & 0,15 & 1.3 & 100,14 \\
\hline ME 146 & 68,85 & 0,52 & 14,72 & 3,39 & 0,07 & 1,27 & 1,38 & 4,16 & 4,54 & 0,14 & 1.9 & 100,94 \\
\hline ME 103.D & 68,86 & 0,38 & 13,41 & 6,06 & 0,16 & 0,78 & 2,76 & 0,67 & 5,92 & 0,09 & 0.8 & 99,09 \\
\hline ME 127 & 69,28 & 0,93 & 13,63 & 6,16 & 0,05 & 0,44 & 1,62 & 2,67 & 4,27 & 0,09 & 1 & 100,14 \\
\hline ME 21.B & 69,37 & 0,48 & 14,57 & 4,55 & 0,06 & 0,19 & 1,95 & 5,1 & 3,59 & 0,13 & 0.2 & 99,99 \\
\hline FET $12 . \mathrm{Z}$ & 69,63 & 0,49 & 15,72 & 2,97 & 0,01 & 0,3 & 0,02 & 0,07 & 9,7 & 0,1 & 0.6 & 99,01 \\
\hline ME 01.A & 70,03 & 0,39 & 14,41 & 3,55 & 0,19 & 0,59 & 1,51 & 2,18 & 6,7 & 0,08 & 0.5 & 99,63 \\
\hline ME 24.A & 70,22 & 0,29 & 14,88 & 3,5 & 0,09 & 0,3 & 2,51 & 3,97 & 3,52 & 0,07 & 0.8 & 99,35 \\
\hline ME 09.A & 70,56 & 0,38 & 14,86 & 2,64 & 0,06 & 0,43 & 2,76 & 3,03 & 3,62 & 0,11 & 1.7 & 98,45 \\
\hline ME 27.A & 70,58 & 0,31 & 14,74 & 3 & 0,06 & 0,6 & 2,89 & 3,38 & 3,1 & 0,08 & 1.8 & 98,74 \\
\hline ME 04.C & 72,77 & 0,26 & 13,5 & 2,81 & 0,04 & 0,26 & 0,85 & 3,02 & 6,03 & 0,04 & 0.5 & 99,58 \\
\hline ME 03.C & 72,95 & 0,25 & 13,76 & 2,48 & 0,09 & 0,25 & 1,31 & 2,92 & 5,55 & 0,04 & 0.6 & 99,6 \\
\hline ME $02.3 \mathrm{~N}$ & 73,89 & 0,23 & 13,35 & 2,25 & 0,04 & 0,29 & 0,88 & 1,79 & 6,46 & 0,04 & 1 & 100,22 \\
\hline ME 76 & 74,49 & 0,2 & 13,13 & 2,45 & 0,03 & 0,16 & 0,27 & 1,27 & 7,29 & 0,03 & 1.3 & 99,32 \\
\hline ME 23.A & 74,54 & 0,25 & 13,4 & 2,02 & 0,04 & 0,19 & 0,88 & 3,45 & 4,89 & 0,05 & 0.5 & 99,71 \\
\hline ME 28.A & 74,77 & 0,14 & 13,47 & 1,62 & 0,17 & 0,13 & 1,43 & 4,25 & 3,7 & 0,04 & 1.3 & 99,72 \\
\hline ME 07 & 75,02 & 0,14 & 12,77 & 2,17 & 0,01 & 0,27 & 0,01 & 0,14 & 8,77 & 0,02 & 0.8 & 99,32 \\
\hline ME 24.B & 75,18 & 0,15 & 13,58 & 1,2 & 0,06 & 0,13 & 0,54 & 4,75 & 4,08 & 0,04 & 0.4 & 99,71 \\
\hline ME 05.A & 75,57 & 0,19 & 12,89 & 1,78 & 0,03 & 0,26 & 0,53 & 2,85 & 5,26 & 0,04 & 0.9 & 99,4 \\
\hline ME 22.B & 75,6 & 0,2 & 12,72 & 1,56 & 0,02 & 0,14 & 0,5 & 2,94 & 5,6 & 0,03 & 0.8 & 99,31 \\
\hline
\end{tabular}


Tabela 2 - Composição química de elementos traços dos vulcanitos estudados.

\begin{tabular}{|c|c|c|c|c|c|c|c|c|c|c|c|c|c|c|c|c|}
\hline Elementos & $\mathrm{Sc}$ & $\mathrm{Ba}$ & $\mathrm{Be}$ & Co & Cs & $\mathrm{Ga}$ & $\mathrm{Hf}$ & $\mathrm{Nb}$ & $\mathrm{Rb}$ & Sn & $\mathrm{Sr}$ & $\mathrm{Ta}$ & Th & $\mathrm{U}$ & $\mathrm{V}$ & $\begin{array}{r}\mathrm{Ga} / \\
\mathrm{Al}\end{array}$ \\
\hline Amostras & ppm & ppm & ppm & ppm & ppm & ppm & ppm & ppm & ppm & ppm & ppm & ppm & ppm & ppm & ppm & \\
\hline ME 25.B & 26 & 324 & 1 & 29,3 & 2,1 & 20 & 2,5 & 4,9 & 83,8 & 1 & 663 & 0,3 & 2 & 0,5 & 246 & 2,16 \\
\hline FET 08.A & 8 & 621 & 2 & 6,2 & 2,5 & 12,8 & 4,1 & 8,5 & 150,7 & 1 & 79,8 & 0,6 & 9,9 & 2,1 & 38 & 2,34 \\
\hline ME 93 & 16 & 743 & 1 & 12,9 & 2,9 & 19,4 & 4,3 & 9 & 77,4 & 1 & 484,9 & 0,8 & 10,7 & 2,8 & 115 & 2,25 \\
\hline ME 92 & 16 & 793 & 2 & 12,5 & 3,3 & 17,2 & 4,4 & 9,3 & 97 & 1 & 315,8 & 0,6 & 11,5 & 2,8 & 100 & 2,02 \\
\hline ME 13.A & 10 & 1181 & 2 & 6,6 & 2 & 15,9 & 7,2 & 12,4 & 122,4 & 1 & 367,5 & 1 & 14,5 & 3,1 & 51 & 1,86 \\
\hline ME 33.B & 13 & 900 & 2 & 8,5 & 3,4 & 17,2 & 7,6 & 13,9 & 150 & 2 & 274 & 1,1 & 15,4 & 3,9 & 62 & 2,24 \\
\hline ME 42 & 4 & 972 & 3 & $<.5$ & 1 & 15,9 & 3,9 & 12,3 & 118,3 & 2 & 166,8 & 1 & 10,5 & 3,6 & & 2,28 \\
\hline ME 41 & 6 & 849 & 2 & 2,9 & 5,9 & 14,2 & 6,7 & 13,2 & 96 & 1 & 374 & 0,8 & 12,7 & 2,9 & 20 & 2,22 \\
\hline ME 32.B & 14 & 1215 & 3 & 7 & 1,6 & 17,6 & 7,1 & 14 & 183,1 & 2 & 223,1 & 1,2 & 13,4 & 3,4 & 67 & 2,26 \\
\hline ME 20.C & 14 & 1145 & 2 & 7,8 & 2,6 & 15,8 & 6,4 & 11,7 & 98,2 & & 237,2 & 0,8 & 10,5 & 2,9 & 56 & 2 \\
\hline ME 12.A & 9 & 1212 & 2 & 5,8 & 1,9 & 16,7 & 6,7 & 12,9 & 137,3 & 1 & 344,7 & 0,9 & 13,1 & 3,4 & 52 & 2,02 \\
\hline ME 11 & 9 & 1134 & 2 & 5,8 & 2,8 & 16,7 & 6,1 & 12,1 & 151,6 & 1 & 370,4 & 0,8 & 13,6 & 3,1 & 45 & 1,98 \\
\hline ME 96 & 8 & 1203 & 2 & 3,1 & 16,1 & 22,4 & 8,5 & 16,5 & 194,4 & 2 & 340,6 & 1,2 & 17,9 & 3,2 & 26 & 2,52 \\
\hline ME 19 & 10 & 1225 & 1 & 5,3 & 1,4 & 16,8 & 6,6 & 13,4 & 145,1 & & 155,4 & 0,9 & 11,4 & 3 & 29 & 2,2 \\
\hline ME 32.A & 13 & 1253 & 2 & 5,9 & 1,6 & 14,7 & 6,9 & 12,7 & 170,5 & 2 & 230,6 & 1 & 12,9 & 3,1 & 57 & 1,99 \\
\hline ME 06.A & 10 & 1798 & 1 & 4,8 & 2,8 & 15,5 & 6,5 & 11,1 & 131,9 & 1 & 179,4 & 0,8 & 10,4 & 2,8 & 37 & 1,99 \\
\hline ME 146 & 10 & 1219 & 1 & 5,9 & 3,2 & 14,3 & 7,4 & 12,2 & 114,4 & 1 & 169,8 & 0,8 & 9,8 & 3,5 & 48 & 1,84 \\
\hline ME 103.D & 7 & 1609 & 1 & 10,3 & 7,4 & 15,2 & 6,1 & 10,6 & 251,1 & 1 & 176 & 1 & 15,2 & 3,9 & 29 & 2,14 \\
\hline ME 127 & 8 & 1380 & 1 & 4,9 & 0,9 & 14,7 & 6,1 & 12,3 & 139,3 & 2 & 219,1 & 0,8 & 10 & 2,7 & 94 & 2,04 \\
\hline ME 21.B & 18 & 1192 & 2 & 2,5 & 0,3 & 17,4 & 8,4 & 14,6 & 92,2 & 1 & 172,5 & 1 & 10 & 2,9 & 21 & 2,26 \\
\hline FET $12 . Z$ & 8 & 989 & 1 & 0,8 & 4,2 & 13,8 & 5,9 & 14,6 & 135 & 1 & 50,8 & 1,1 & 12,9 & 3,6 & 25 & 1,66 \\
\hline ME 01.A & 9 & 1534 & 2 & 4 & 7,6 & 15,8 & 8,1 & 13,5 & 270,8 & 2 & 124,9 & 1,1 & 14,4 & 3,9 & 21 & 2,07 \\
\hline ME 24.A & 16 & 948 & 3 & 2,5 & 3,5 & 17,1 & 9,5 & 14,4 & 119,7 & 2 & 314,9 & 1 & 12,1 & 3,1 & & 2,17 \\
\hline ME 09.A & 7 & 943 & 2 & 2,9 & 2,6 & 16,5 & 5,7 & 11,9 & 132,7 & 1 & 217,6 & 0,8 & 11,4 & 3 & 33 & 2,1 \\
\hline ME 27.A & 11 & 719 & 2 & 3,7 & 2,4 & 16,3 & 5,1 & 10,9 & 122,2 & 1 & 223,5 & 0,8 & 11,2 & 2,9 & 21 & 2,09 \\
\hline ME 04.C & 7 & 1507 & 2 & 2,6 & 1,1 & 14,4 & 8 & 14,2 & 159,1 & 2 & 139,6 & 1,1 & 15,7 & 4,2 & 6 & 2,02 \\
\hline ME 03.C & 7 & 1333 & 2 & 2,1 & 3 & 13,8 & 8,5 & 13,6 & 187,1 & 2 & 137,6 & 1 & 13 & 3,6 & 7 & 1,89 \\
\hline $\mathrm{ME} 02.3 \mathrm{~N}$ & 6 & 1460 & 1 & 1,1 & 3,1 & 14 & 8,2 & 13,9 & 234 & 2 & 72,1 & 1,1 & 15,6 & 3,9 & 9 & 1,98 \\
\hline ME 76 & 6 & 2280 & 1 & 1,1 & 2 & 13,7 & 6,8 & 13,4 & 242 & 2 & 60,4 & 1 & 18,5 & 4,4 & & 1,97 \\
\hline ME 23.A & 6 & 1188 & 2 & 1,6 & 0,7 & 14,8 & 6,5 & 12,4 & 146,6 & 2 & 90,4 & 1 & 13,8 & 3,8 & 7 & 2,09 \\
\hline ME 28.A & 4 & 1023 & 3 & 0,5 & 1 & 16,9 & 4,2 & 12,7 & 126,6 & 2 & 178,5 & 1 & 11,3 & 3,5 & & 2,37 \\
\hline ME 07 & 5 & 1496 & & 1 & 0,7 & 11,6 & 6,3 & 15,6 & 199,8 & 2 & 14,6 & 1,2 & 16,5 & 3,1 & & 1,72 \\
\hline ME 24.B & 4 & 1315 & 2 & 0,5 & 1,1 & 14,8 & 5,1 & 14,7 & 126,8 & 2 & 96,1 & 0,9 & 11,3 & 2,7 & & 2,06 \\
\hline ME 05.A & 5 & 785 & 1 & 1,7 & 0,9 & 12,9 & 5,5 & 13,8 & 152,2 & 2 & 90,1 & 1,2 & 22,7 & 5,8 & 12 & 1,89 \\
\hline ME 22.B & 5 & 1075 & 1 & 1,1 & 0,4 & 13,9 & 5,9 & 11,9 & 141,9 & 2 & 69,5 & 1 & 14,7 & 4 & & 2,06 \\
\hline
\end{tabular}


Tabela 2 - continuação.

\begin{tabular}{|c|c|c|c|c|c|c|c|c|c|c|c|c|c|c|c|}
\hline Elementos & W & $\mathrm{Zr}$ & $\mathrm{Y}$ & Mo & $\mathrm{Cu}$ & $\mathrm{Pb}$ & $\mathrm{Zn}$ & $\mathrm{Ni}$ & As & $\mathrm{Sb}$ & $\mathrm{Bi}$ & $\mathrm{Ag}$ & $\mathrm{Au}$ & $\mathrm{Tl}$ & $\mathrm{Zr} / \mathrm{Y}$ \\
\hline Amostras & ppm & ppm & ppm & ppm & ppm & ppm & ppm & ppm & ppm & ppm & ppm & ppm & $\mathrm{ppb}$ & ppm & \\
\hline ME 25.B & 1,8 & 76,8 & 17,8 & 1,8 & 144,1 & 1,2 & 50 & 16,4 & 0,5 & 0,1 & & & 0,5 & 0,1 & 4,31 \\
\hline FET 08.A & 2,6 & 142,6 & 22,9 & 2,6 & 3,5 & 8,7 & 10 & 3,2 & 0,9 & 2,4 & 0,2 & & & & 6,23 \\
\hline ME 93 & 3,2 & 166,4 & 29 & 3,2 & 19,7 & 2,3 & 41 & 12,8 & 0,6 & 0,1 & & & & 0,2 & 5,74 \\
\hline ME 92 & 1,8 & 166,1 & 28,8 & 1,8 & 29,8 & 2,4 & 59 & 11,9 & 1 & 0,1 & & & 1,3 & 0,2 & 5,77 \\
\hline ME 13.A & 3,6 & 230,3 & 31,6 & 3,6 & 19,4 & 3,9 & 73 & 5 & & 0,5 & 0,2 & & & 0,3 & 7,29 \\
\hline ME 33.B & 1,2 & 271,5 & 35,5 & 1,2 & 23,2 & 13,2 & 55 & 6,3 & 1 & 0,2 & 0,1 & & 1,9 & 0,1 & 7,65 \\
\hline ME 42 & 2,1 & 120,2 & 35,6 & 2,1 & 3,1 & 16,3 & 56 & 1,3 & & 0,2 & 0,1 & & 1,1 & & 3,38 \\
\hline ME 41 & 6,8 & 219,9 & 98,8 & 6,8 & 3,2 & 17,8 & 38 & 1,8 & 2 & 0,8 & 0,2 & & 1 & 0,1 & 2,23 \\
\hline ME 32.B & 5,4 & 286 & 38,1 & 5,4 & 2,1 & 4,4 & 15 & 6,1 & 0,8 & 0,4 & 0,1 & & & & 7,51 \\
\hline ME 20.C & 1,7 & 230,7 & 33,4 & 1,7 & 1,2 & 2,4 & 11 & 3,3 & & & 0,1 & & & 0,1 & 6,91 \\
\hline ME 12.A & 1,4 & 226,8 & 42,5 & 1,4 & 16,8 & 5,8 & 60 & 4,3 & 1,5 & 0,3 & & & 1,1 & 0,3 & 5,34 \\
\hline ME 11 & 6,6 & 222,4 & 25,5 & 6,6 & 15,1 & 7,5 & 45 & 4,6 & 1 & 0,1 & 0,1 & & 0,7 & 0,3 & 8,72 \\
\hline ME 96 & 1,4 & 294,6 & 67 & 1,4 & 1,9 & 7,4 & 82 & 1,7 & 1,6 & 0,6 & 0,1 & & & 0,2 & 4,4 \\
\hline ME 19 & 1,7 & 225,8 & 39,6 & 1,7 & 3,9 & 10,7 & 32 & 2,5 & 2,4 & 0,3 & & & 1,8 & 0,1 & 5,7 \\
\hline ME 32.A & 1,9 & 254,3 & 33,8 & 1,9 & 2,1 & 7 & 17 & 6,9 & 0,6 & 0,3 & 0,2 & & 0,9 & & 7,52 \\
\hline ME 06.A & 1,9 & 228,9 & 34,6 & 1,9 & 2 & 2,4 & 12 & 1,9 & 5,5 & 0,5 & 0,1 & & 1,5 & 0,1 & 6,62 \\
\hline ME 146 & 3,8 & 254,7 & 27,3 & 3,8 & 28,4 & 4,7 & 33 & 2,4 & 0,5 & 0,4 & 0,1 & & 2,3 & 0,2 & 9,33 \\
\hline ME 103.D & 3,8 & 210,6 & 31,4 & 3,8 & 81 & 6,6 & 93 & 4,1 & & 0,3 & 0,7 & 0,7 & 1 & 1 & 6,71 \\
\hline ME 127 & 1,9 & 212,7 & 32,1 & 1,9 & 2 & 1,9 & 15 & 4,7 & & 0,2 & 0,1 & & 1,2 & 0,1 & 6,63 \\
\hline ME 21.B & 1,6 & 338,7 & 46,5 & 1,6 & 2,1 & 3,5 & 21 & 2,5 & 1,2 & 0,1 & & & & & 7,28 \\
\hline FET $12 . Z$ & 2,2 & 239,3 & 236,2 & 2,2 & 2,5 & 4,3 & 2 & 1,1 & 0,6 & 0,7 & & & & & 1,01 \\
\hline ME 01.A & 4,2 & 279,9 & 34,3 & 4,2 & 13,1 & 50,5 & 442 & 2,1 & 1,5 & 0,5 & 0,2 & 0,1 & 2,1 & 1 & 8,16 \\
\hline ME 24.A & 3,6 & 338,1 & 33,9 & 3,6 & 4,4 & 8,6 & 58 & 1,5 & & 0,1 & & & 1,4 & 0,3 & 9,97 \\
\hline ME 09.A & 1,4 & 202,5 & 57,3 & 1,4 & 2,5 & 3,6 & 14 & 1,3 & 0,8 & 0,1 & 0,1 & & & 0,1 & 3,53 \\
\hline ME 27.A & 4,4 & 178,6 & 28,2 & 4,4 & 10,9 & 6,5 & 43 & 3,1 & & 0,1 & 0,1 & & & 0,2 & 6,33 \\
\hline ME 04.C & 1,7 & 266,5 & 37,5 & 1,7 & 23,9 & 6,5 & 19 & 1,3 & & 0,3 & 0,1 & & 0,8 & 0,2 & 7,11 \\
\hline ME 03.C & 4,5 & 261,4 & 37,3 & 4,5 & 8,5 & 5,7 & 60 & 0,8 & 0,9 & 0,2 & 0,1 & & 2,1 & 0,3 & 7,01 \\
\hline ME $02.3 \mathrm{~N}$ & 2,9 & 245,4 & 27,5 & 2,9 & 3,8 & 2,7 & 18 & 0,6 & & 0,1 & 0,1 & & 2,3 & 0,3 & 8,92 \\
\hline ME 76 & 6,8 & 238,5 & 50,1 & 6,8 & 2,2 & 13,6 & 12 & 1 & 0,5 & 0,5 & 0,1 & & 0,6 & 0,1 & 4,76 \\
\hline ME 23.A & 1,4 & 211,1 & 32,9 & 1,4 & 4,3 & 4,4 & 11 & 1,2 & & 0,2 & 0,1 & & 1,3 & 0,1 & 6,42 \\
\hline ME 28.A & 7,2 & 128,9 & 36,7 & 7,2 & 3,4 & 15,8 & 59 & 1,3 & & 0,1 & 0,1 & & 2 & & 3,51 \\
\hline ME 07 & 12,2 & 176,5 & 33,1 & 12,2 & 1,5 & 2,1 & 5 & 0,7 & & 0,3 & & & 1,6 & & 5,33 \\
\hline ME 24.B & 2,2 & 146 & 28,1 & 2,2 & 2,4 & 5,1 & 17 & 1,3 & & 0,1 & & & 2,7 & & 5,2 \\
\hline ME 05.A & 4,7 & 150,8 & 36,7 & 4,7 & 10,5 & 8,8 & 14 & 1,6 & 0,9 & 0,3 & 0,1 & & 0,8 & & 4,11 \\
\hline ME 22.B & 5,4 & 172,4 & 90,2 & 5,4 & 2,8 & 3,1 & 4 & 0,8 & & 0,1 & 0,1 & & & & 1,91 \\
\hline
\end{tabular}


Tabela 3 - Composição química de ETR.

\begin{tabular}{|c|c|c|c|c|c|c|c|c|c|c|c|c|c|c|c|c|}
\hline \multirow{2}{*}{ Elementos } & \multirow{2}{*}{$\mathrm{La}$} & \multirow{2}{*}{$\mathrm{Ce}$} & \multirow{2}{*}{$\operatorname{Pr}$} & \multirow{2}{*}{$\mathrm{Nd}$} & \multirow{2}{*}{$\mathrm{Sm}$} & \multirow{2}{*}{$\mathrm{Eu}$} & \multirow{2}{*}{$\mathrm{Gd}$} & \multirow{2}{*}{$\mathrm{Tb}$} & \multirow{2}{*}{ Dy } & \multirow{2}{*}{ Но } & \multirow{2}{*}{ Er } & \multirow{2}{*}{$\mathrm{Tm}$} & \multirow{2}{*}{$\mathrm{Yb}$} & \multirow{2}{*}{$\mathrm{Lu}$} & \multirow{2}{*}{$\begin{array}{l}\mathrm{Eu} / \\
\mathrm{Eu}^{*}\end{array}$} & \multirow{2}{*}{$\begin{array}{l}(\mathrm{La} / \\
\mathrm{Yb})\end{array}$} \\
\hline & & & & & & & & & & & & & & & & \\
\hline ME 25.B & 20,8 & 45 & 6 & 24 & 5 & 1,37 & 3,85 & 0,6 & 3,2 & 0,6 & 1,7 & 0,3 & 1,76 & 0,2 & 0,96 & 7,88 \\
\hline FET 08A & 32,3 & 69 & 8 & 30 & 5,5 & 0,99 & 4,11 & 0,7 & 3,7 & 0,8 & 2,3 & 0,4 & 2,17 & 0,3 & 0,64 & 9,92 \\
\hline ME 93 & 36,2 & 77 & 9 & 34 & 6,3 & 1,47 & 4,92 & 0,9 & 4,9 & 1 & 3 & 0,4 & 2,88 & 0,2 & 0,81 & 8,38 \\
\hline ME 92 & 36,8 & 74 & 9 & 33 & 7,1 & 1,29 & 4,86 & 0,9 & 5,3 & 1,1 & 2,9 & 0,4 & 2,93 & 0,5 & 0,68 & 8,37 \\
\hline ME 13.A & 34,5 & 80 & 8 & 29 & 5,3 & 1,12 & 4,69 & 0,8 & 4,4 & 0,9 & 2,9 & 0,5 & 3,26 & 0,4 & 0,69 & 7,06 \\
\hline ME 33.B & 40,5 & 90 & 11 & 40 & 7,3 & 1,44 & 5,99 & 0,9 & 5,5 & 1,1 & 3,4 & 0,5 & 3,66 & 0,6 & 0,67 & 7,38 \\
\hline ME 42 & 34,6 & 72 & 9 & 35 & 6,4 & 1,14 & 5,92 & 1 & 5,7 & 1,2 & 3,3 & 0,6 & 3,36 & 0,6 & 0,57 & 6,87 \\
\hline ME 41 & 126,4 & 103 & 27 & 101 & 17,8 & 4,37 & 17,78 & 2,8 & 15,6 & 3,3 & 8,9 & 1,4 & 7,69 & 1,2 & 0,76 & 10,96 \\
\hline ME 32.B & 43,7 & 92 & 11 & 41 & 7,8 & 1,57 & 6,33 & 1,1 & 6,1 & 1,3 & 3,8 & 0,6 & 3,95 & 0,6 & 0,69 & 7,38 \\
\hline ME 20.C & 34,2 & 67 & 9 & 34 & 6,4 & 1,41 & 5,86 & 1 & 5,3 & 1,1 & 3,2 & 0,5 & 3,17 & 0,5 & 0,71 & 7,19 \\
\hline ME 12.A & 52,2 & 92 & 12 & 45 & 8,3 & 1,61 & 7,08 & 1,1 & 6,3 & 1,3 & 4 & 0,6 & 4,16 & 0,5 & 0,65 & 8,37 \\
\hline ME 11 & 30,9 & 68 & 8 & 30 & 5 & 1,09 & 3,79 & 0,6 & 3,6 & 0,8 & 2,7 & 0,4 & 2,57 & 0,4 & 0,77 & 8,02 \\
\hline ME 96 & 98,4 & 163 & 23 & 84 & 15 & 2,85 & 10,91 & 1,7 & 9,5 & 2 & 5,5 & 0,8 & 5,76 & 0,9 & 0,68 & 11,39 \\
\hline ME 19 & 41 & 86 & 10 & 37 & 7,9 & 1,58 & 6,03 & 1,2 & 6,9 & 1,3 & 4 & 0,6 & 4,09 & 0,6 & 0,7 & 6,68 \\
\hline ME 32.A & 39,9 & 85 & 10 & 37 & 7,2 & 1,36 & 5,71 & 10 & 5,7 & 1,1 & 3,3 & 0,5 & 3,19 & 0,5 & 0,65 & 8,34 \\
\hline ME 06.A & 40,5 & 83 & 10 & 37 & 6,2 & 1,24 & 5,57 & 0,9 & 5,5 & 1 & 3,5 & 0,5 & 3,33 & 0,6 & 0,65 & 8,11 \\
\hline ME 146 & 40,5 & 82 & 10 & 36 & 6,8 & 1,33 & 4,53 & 0,8 & 4,5 & 0,9 & 2,7 & 0,5 & 2,75 & 0,5 & 0,74 & 9,82 \\
\hline ME 103D & 39,1 & 83 & 9 & 31 & 6,3 & 1,18 & 5,14 & 0,8 & 4,9 & 1 & 3,2 & 0,4 & 3,16 & 0,5 & 0,64 & 8,25 \\
\hline ME 127 & 36,8 & 72 & 9 & 33 & 5,6 & 1,4 & 4,18 & 0,8 & 4,8 & 1 & 3,1 & 0,5 & 2,81 & 0,4 & 0,89 & 8,73 \\
\hline ME 21.B & 50,6 & 98 & 13 & 48 & 8,8 & 2,02 & 7,8 & 1,1 & 7,6 & 1,6 & 4,4 & 0,7 & 4,39 & 0,7 & 0,75 & 7,68 \\
\hline FET $12 Z$ & 197,3 & 109 & 63 & 275 & 47,9 & 11,08 & 44,01 & 5,5 & 30,8 & 6,3 & 17,8 & 2,4 & 14,18 & 2,3 & 0,74 & 9,28 \\
\hline ME 01.A & 41,5 & 86 & 10 & 37 & 7,4 & 1,19 & 5,61 & 1 & 5,4 & 1,1 & 3,3 & 0,6 & 3,81 & 0,5 & 0,57 & 7,26 \\
\hline ME 24.A & 53,6 & 110 & 13 & 47 & 8,4 & 1,98 & 6,67 & 1,1 & 5,9 & 1,1 & 3,5 & 0,5 & 3,5 & 0,5 & 0,81 & 10,21 \\
\hline ME 09.A & 62,5 & 107 & 13 & 50 & 8,7 & 1,88 & 8,11 & 1,3 & 7,6 & 1,7 & 4,9 & 0,8 & 4,8 & 0,7 & 0,69 & 8,68 \\
\hline ME 27.A & 41 & 87 & 10 & 39 & 6,6 & 1,23 & 5,38 & 0,9 & 4,8 & 0,9 & 2,9 & 0,4 & 2,68 & 0,4 & 0,63 & 10,2 \\
\hline ME 04.C & 44,4 & 90 & 10 & 41 & 6,8 & 0,93 & 6,24 & 1 & 6,5 & 1,2 & 3,7 & 0,6 & 3,7 & 0,6 & 0,44 & 8 \\
\hline ME 03.C & 46 & 94 & 11 & 39 & 7 & 1 & 5,76 & 1 & 5,9 & 1,1 & 3,6 & 0,6 & 3,75 & 0,5 & 0,48 & 8,18 \\
\hline ME $02.3 \mathrm{~N}$ & 34,2 & 71 & 8 & 29 & 4,8 & 0,72 & 4,26 & 0,8 & 4,5 & 0,9 & 3 & 0,4 & 3,3 & 0,4 & 0,49 & 6,91 \\
\hline ME 76 & 54,6 & 102 & 13 & 46 & 8,7 & 0,94 & 7,1 & 1,1 & 7,2 & 1,6 & 4,9 & 0,7 & 4,35 & 0,7 & 0,37 & 8,37 \\
\hline ME 23.A & 31,2 & 69 & 7 & 25 & 5,2 & 0,8 & 3,99 & 0,4 & 4,9 & 1 & 3,4 & 0,5 & 3,98 & 0,6 & 0,54 & 5,23 \\
\hline ME 28.A & 33,2 & 75 & 9 & 34 & 6,7 & 1,05 & 5,55 & 0,9 & 5,3 & 1,1 & 3,3 & 0,5 & 3,23 & 0,5 & 0,53 & 6,85 \\
\hline ME 07 & 42,6 & 97 & 12 & 41 & 7,1 & 0,43 & 5,3 & 0,9 & 5,6 & 1,1 & 3,5 & 0,6 & 4,5 & 0,6 & 0,22 & 6,31 \\
\hline ME 24.B & 41,3 & 86 & 10 & 34 & 6,4 & 0,97 & 4,59 & 0,8 & 4,7 & 0,9 & 2,7 & 0,4 & 2,95 & 0,4 & 0,55 & 9,33 \\
\hline ME 05.A & 42,8 & 54 & 10 & 33 & 6 & 0,68 & 4,93 & 0,9 & 5,8 & 1,1 & 3,9 & 0,6 & 4,38 & 0,3 & 0,38 & 6,51 \\
\hline ME 22.B & 144,6 & 112 & 28 & 101 & 17,2 & 2,23 & 15,9 & 2,5 & 14,5 & 2,9 & 8,4 & 1,2 & 7,11 & 1,1 & 0,41 & 13,56 \\
\hline
\end{tabular}




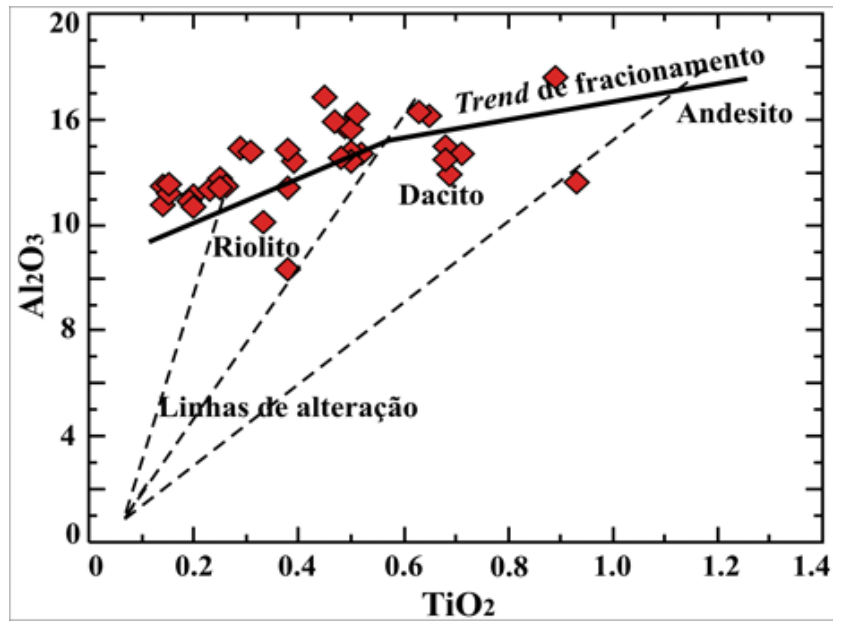

Figura 5 - Distribuição dos pontos representativos no diagrama $\mathrm{Al}_{2} \mathrm{O}_{3}$ versus $\mathrm{TiO}_{2}$ (Cattalani \& Bambic 1994, in: Leite et al. 2005).

indicando mobilização destes elementos, e foram descartadas no tratamento geoquímico, sendo utilizados apenas seus dados de ETR.

Os diagramas de variação binários de Harker (Fig. 6) mostram, em geral, tendências de variação coerentes, com uma possível evolução por cristalização fracionada para as rochas estudadas. Observam-se correlações lineares negativas com a sílica para $\mathrm{Al}_{2} \mathrm{O}_{3}$, $\mathrm{Fe}_{2} \mathrm{O}_{3}, \mathrm{MgO}, \mathrm{CaO} \mathrm{TiO}_{2}, \mathrm{P}_{2} \mathrm{O}_{5}$, devido ao incremento dos teores modais de quartzo, empobrecimento da molécula de anortita dos plagioclásios e em minerais máficos primários, tais como hornblenda, biotita, ilmenita, magnetita, titanita e apatita, durante a diferenciação. O comportamento de $\mathrm{MnO}$ e dos álcalis $\left(\mathrm{Na}_{2} \mathrm{O}\right.$ e $\left.\mathrm{K}_{2} \mathrm{O}\right)$ não evidenciam um padrão de diferenciação, com relativa dispersão em função dos baixos teores de Mn e da maior mobilidade de $\mathrm{Na}$ e $\mathrm{K}$ durante a atuação de processos pós-magmáticos. Entre os elementos traços, $\mathrm{Sr}, \mathrm{Zr}$ e V apresentam distribuições relativamente semelhantes $\mathrm{e}$ correlações negativas com a sílica. A diminuição do $\mathrm{Sr}$ define tendências coerentes com processos de diferenciação envolvendo fracionamento de plagioclásio, também sugerido pelo comportamento do $\mathrm{CaO}$ e pela anomalia negativa de Eu, ilustrada na figura 11B. Já os decréscimos de $\mathrm{V}$ e $\mathrm{Zr}$ estão vinculados ao empobrecimento em minerais máficos primários (hornblenda e biotita) e ao fracionamento de zircão, respectivamente.

Em concordância com o estudo petrográfico, a maioria dos vulcanitos da PITP é classificada como riolitos, traqui-dacitos e dacitos nos diagramas álcalis versus sílica de Le Maitre (2002; Fig. 7A) e como riolitos, riodacitos-dacitos naquele proposto por Winchester \& Floyd (1977) que utiliza, além de $\mathrm{SiO}_{2}$, elementos considerados menos móveis nos processos pós-magmáticos, tais como $\mathrm{Zr}$ e $\mathrm{TiO}_{2}$ (Fig. 7B). No diagrama classificatório R1-R2 (La Roche et al. 1980; Fig. 7C) plotam preferencialmente nos domínios de riolitos, riodacitos e dacitos.
O magmatismo que originou as rochas estudadas possui caráter subalcalino e, aparentemente, maior afinidade com as séries cálcio-alcalinas, respectivamente nos diagramas álcalis versus $\mathrm{SiO}_{2}$ e AFM (Irvine \& Baragar 1971; Figs. 8A e 8B). Os pontos que as representam descrevem na figura $8 \mathrm{~B}$ uma tendência aproximadamente linear que evolui em direção ao vértice dos álcalis, para valores decrescentes de $\mathrm{FeO}_{\mathrm{t}}$ e $\mathrm{MgO}$. A natureza cálcio-alcalina desse magmatismo é também sugerida pelo fato das amostras analisadas apresentarem razões $\mathrm{La} / \mathrm{Yb}$ maiores do que 6 (Fig. 8C; campos segundo Barret \& MacLean 1999) e pela interseção dos trends do total de álcalis e CaO versus $\mathrm{SiO}_{2}$ (Fig. 8D) no diagrama de Peacock (1931). Segundo o diagrama A/CNK versus A/NK (Maniar \& Piccoli 1989), as rochas estudadas são classificadas como metaluminosas a peraluminosas, com predomínio deste caráter (Fig. 8E), apresentando discreto crescimento do grau de saturação em alumina com a evolução magmática e com o aumento da cloritização, processo que segundo Scheepers (1995) acarreta um incremento deste índice.

As razões $\mathrm{Ga} / \mathrm{Al}$ utilizadas como discriminantes de granitos tipo I, S e A (Whalen et al. 1987; Fig. 9) indicam que as rochas estudadas não são granitóides do tipo A, que são caracterizados por valores elevados dessa razão. Quando considerando elementos pouco móveis ou praticamente imóveis em processos posteriores à cristalização magmática, os resultados obtidos confirmam essa hipótese. Já os dados petrográficos e diagramas geoquímicos apresentados anteriormente excluem a relação com granitos tipo $\mathrm{S}$ e revelam que essas rochas possuem afinidade com granitos do tipo I. As amostras ME-96 e ME-01 se deslocam para o domínio proposto para granitóides do tipo A por apresentarem, respectivamente, altos teores de Ce (163 ppm) e de Zn (442 ppm) justificados pela presença de allanita na primeira e esfalerita formada por processo hidrotermal na segunda. Fogem também a esse padrão algumas amostras que apresentam altos teores de $\mathrm{K}_{2} \mathrm{O}$, provenientes de alteração.

Em diagramas discriminantes de ambientes tectônicos, baseados no comportamento de $\mathrm{Hf}-\mathrm{Rb}-\mathrm{Ta}$ (Fig. 10A), as rochas da PITP concentram-se no domínio proposto para granitóides de arco vulcânico (Harris et al. 1986, in: Sylvester 1989). No diagrama Rb versus $(\mathrm{Y}+\mathrm{Nb})$ (Pearce et al. 1984; Fig. 10B) algumas amostras encontram-se deslocadas para o campo dos granitóides intraplaca (WPG), possivelmente devido a um enriquecimento em Y alojado em cristais de allanita e/ ou titanita. No entanto todas coincidem com ambiente pós-colisional conforme proposto por Pearce (1996).

A normalização dos teores dos elementos traços e do $\mathrm{K}_{2} \mathrm{O}$, a partir dos granitos de Cordilheira Meso-Oceânica (Pearce et al. 1984; Fig. 11A), evidencia um enriquecimento seletivo em elementos litófilos de íons grandes (LILE) $\mathrm{K}, \mathrm{Rb}, \mathrm{Ba}$ e Th em relação aos de alta carga (HFSE), Ta, Nb, Ce, Hf, Zr, Sm, Y e Yb. No grupo dos LILE observa-se anomalia positiva de $\mathrm{Rb}$ e no dos HFSE é nítida uma anomalia positiva de $\mathrm{Ce}$, sugerindo uma provável interação com a água do mar (Munhá \& Kerrich 1980) ou baixos teores de Nb e Hf. 


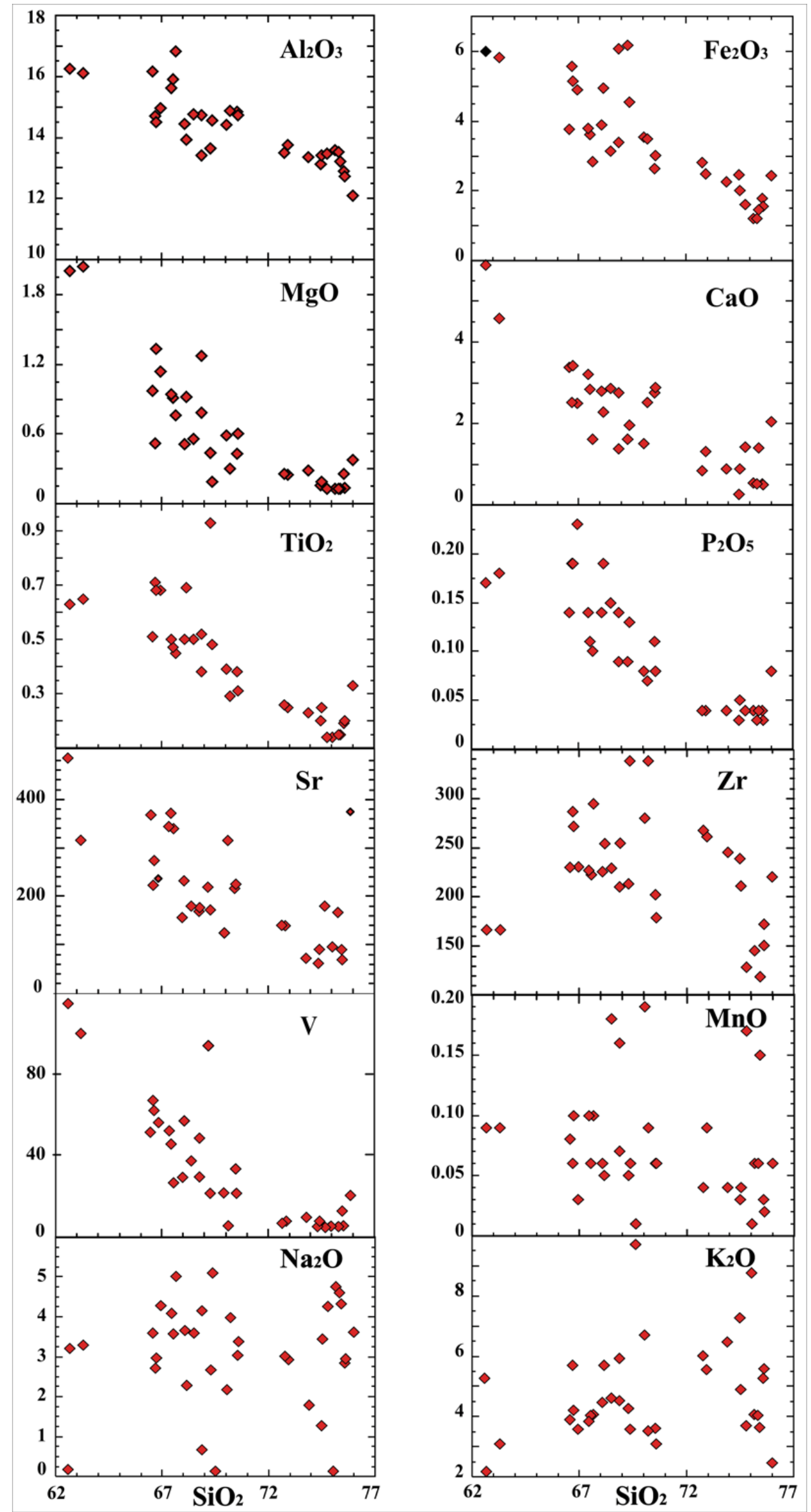

Figura 6 - Variação composicional nos diagramas $\mathrm{SiO}_{2}$ versus óxidos e elementos menores e traços. 

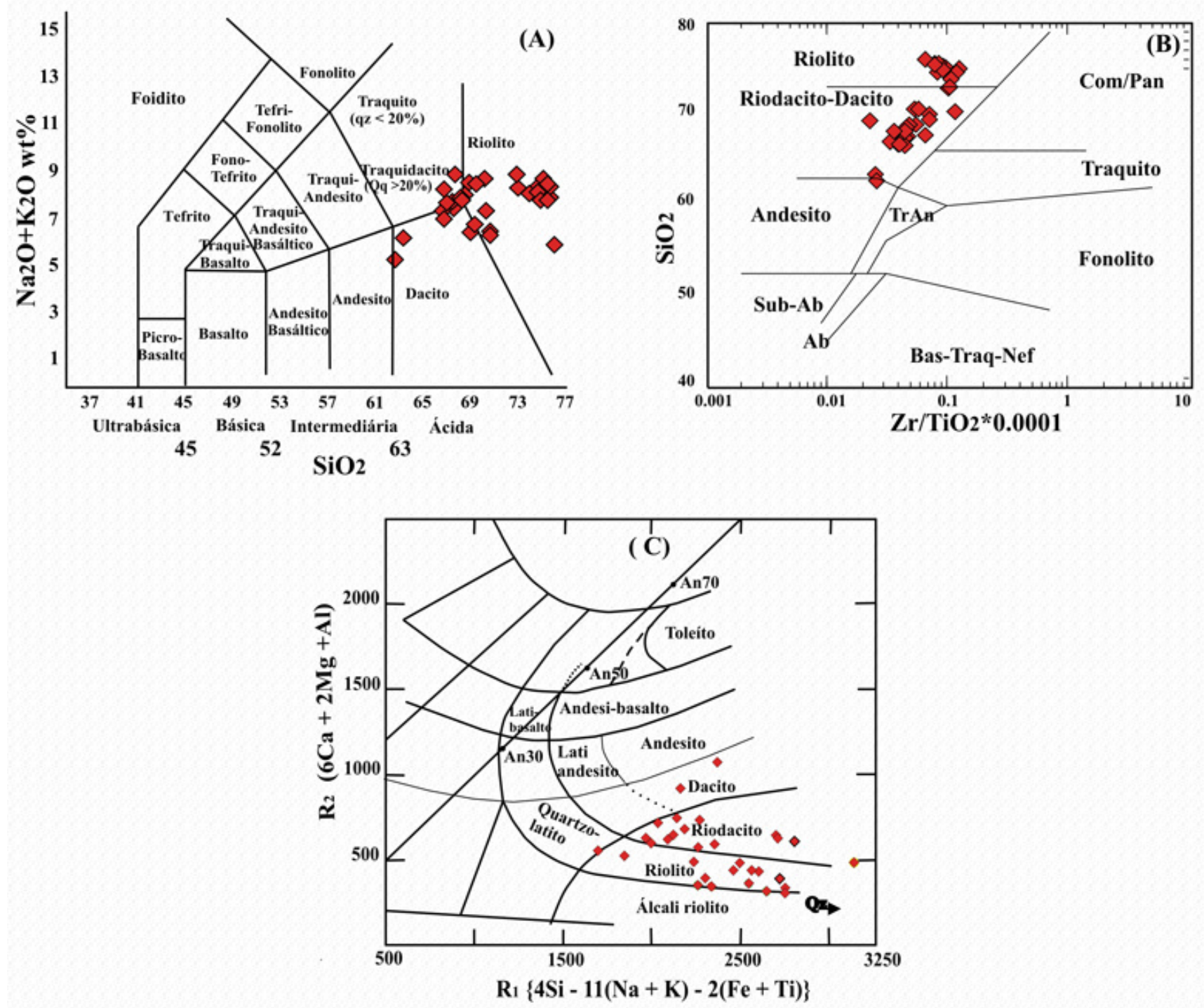

Figura 7 - Variação composicional nos diagramas: (A) total de álcalis versus sílica (Le Maitre 2002); (B) $\mathrm{SiO}_{2}$ versus $\mathrm{Zr} / \mathrm{TiO}_{2}$ (Winchester \& Floyd 1977); (C) R1-R2 (La Roche et al. 1980).

Apresenta um padrão sub-horizontalizado para $\mathrm{Hf}, \mathrm{Zr}$, $\mathrm{Y} \mathrm{e} \mathrm{Yb}$, quase sempre inferior a 1 , semelhante àquele encontrado em rochas cálcio-alcalinas de alto K (Scheepers 1995), como os granitóides de arco magmático continental da Cordilheira Oeste dos Andes.

Os padrões dos ETR, normalizados pelos valores condríticos de Nakamura (1977), apresentam anomalias negativas de Eu (Fig. 11B), sugerindo diferenciação com forte fracionamento de plagioclásio. É nítido o fracionamento dos ETRP em relação aos ETRL, os primeiros exibindo configuração sub-horizontalizada, padrão similar àqueles encontrados em rochas cálcio-alcalinas modernas, para as quais tem sido atribuída uma origem a partir da fusão parcial de uma crosta continental pré-existente, com um componente mantélico subordinado. Em relação ao envelope representativo das amostras tidas como menos alteradas (Fig. 11C), as rochas mais afetadas por hidroter- malismo mostram um considerável espalhamento vertical, no entanto paralelizado àquele envelope, o que pode sugerir uma proporcional concentração dos ETR em relação à perda de elementos mais móveis em processos posteriores à cristalização. Observa-se também, para quatro amostras do conjunto, um incremento da anomalia negativa de $\mathrm{Ce}$, sugerindo provável interação com água do mar (Rollinson 1993). A grande maioria das amostras apresenta razões médias de $\mathrm{Eu} / \mathrm{Eu}^{*}$ em torno de 0,6 , com variação entre 0,5 e 0,89 , mostrando anomalias negativas desse elemento de moderadas a suaves, que aumentam proporcionalmente com a diferenciação magmática. Do conjunto analisado, destacam-se algumas amostras com forte anomalia de Eu; dentre elas, seis de composição riolítica com razões entre 0,37 e 0,49 e uma caracterizada quimicamente por altos teores de $\mathrm{SiO}_{2}(75 \%)$ e $\mathrm{K}_{2} \mathrm{O}(8,8 \%)$, com intensa alteração hidrotermal (sericitização, argilização e 

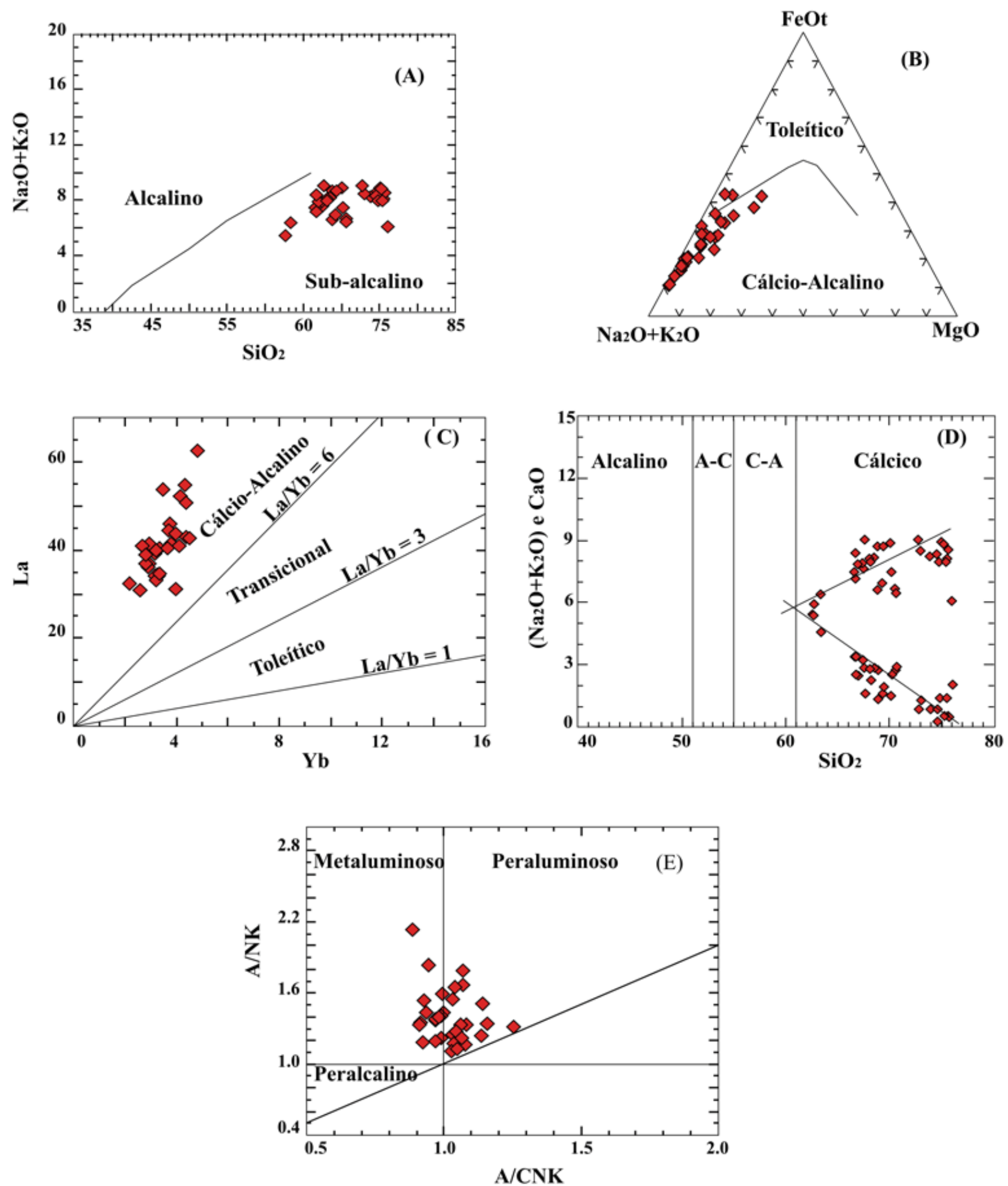

Figura 8 - Variação composicional em diagramas: (A) total de álcalis versus sílica e (B) AFM (Irvine \& Baragar 1971); (C) La versus Yb (Barret \& MacLean 1999); (D) total de álcalis e CaO versus sílica (Peacock 1931); (E) A/NK versus A/CNK (Maniar \& Piccoli 1989).

silicificação) e razão $\mathrm{Eu} / \mathrm{Eu}^{*}$ de 0,22.

CONSIDERAÇÕES FINAIS ECONCLUSÕES As rochas da PITP na região dos municípios de Juína, Castanheira e Juruena constituem uma seqüência vulcânica explosiva e são geneticamente classificadas como ignimbritos (Sparks et al. 1973, Cas \& Wright 1987 e William \& Mc Birney 1979), utilizado para designar depósitos piroclásticos de alta temperatura, constituídos dominantemente por fluxos de púmice, independente do grau de soldagem ou volume. Esses ignimbritos foram petrograficamente individualizados como 

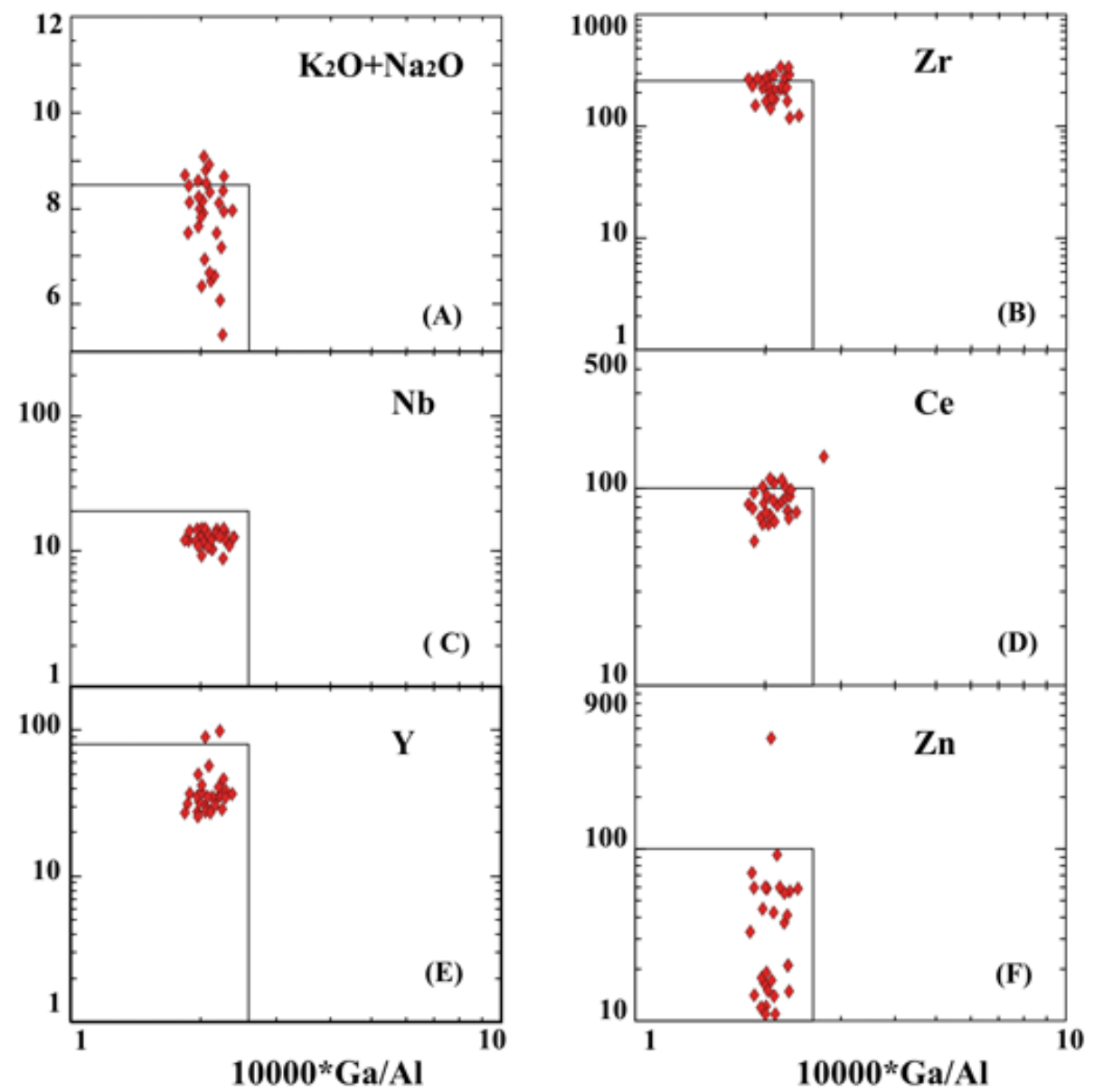

Figura 9 - Distribuição dos pontos representativos dos vulcanitos estudados nos diagramas propostos por Whalen et al. (1987): $10000^{*} \mathrm{Ga} / \mathrm{Al}$ versus $\mathrm{K}_{2} \mathrm{O}+\mathrm{Na}_{2} \mathrm{O}(\mathrm{A}) ; \mathrm{Zr}(\mathrm{B}) ; \mathrm{Nb}(\mathrm{C}) ; \mathrm{Ce}(\mathrm{D}) ; \mathrm{Y}(\mathrm{E}) ; \mathrm{Zn}(\mathrm{F})$.
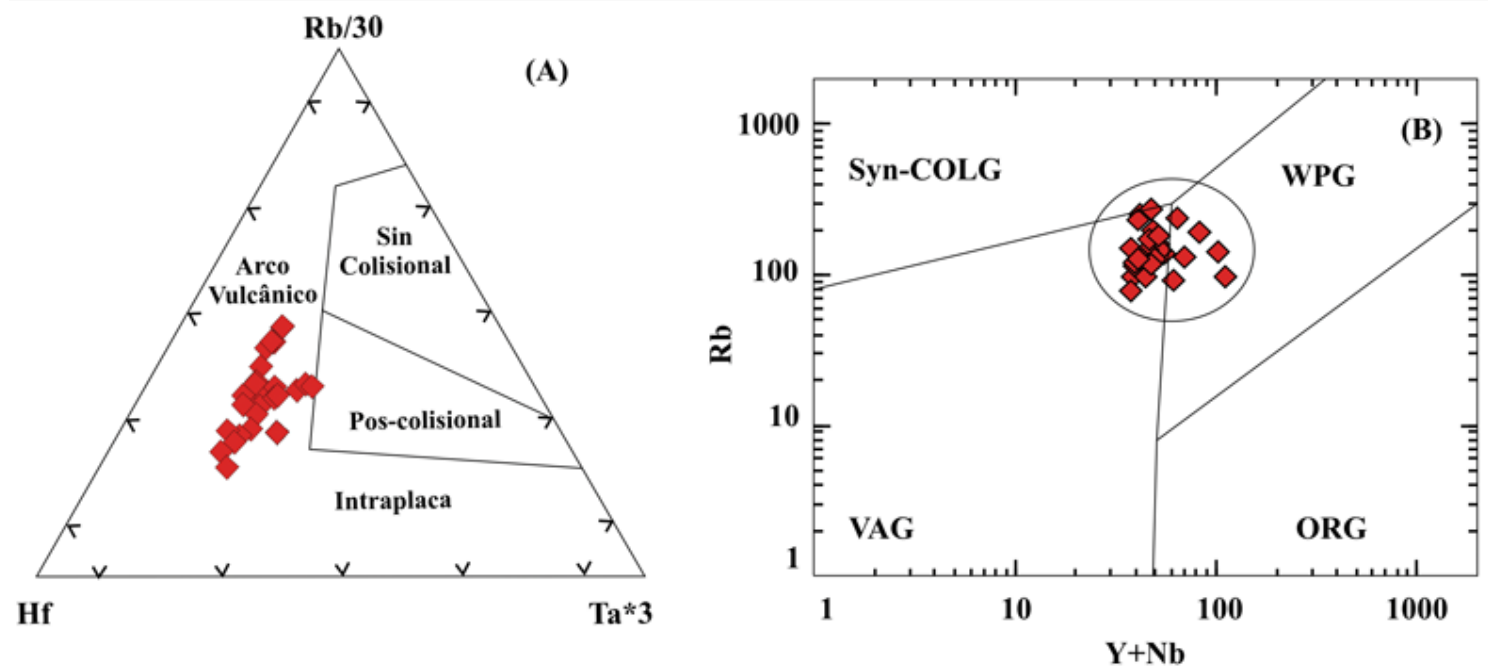

Figura 10 - Variação composicional dos vulcanitos estudados nos diagramas: (A) Hf-Rb/30Ta*3 (Harris et al., in: Sylvester 1989); (B) Rb versus Y+Nb (Pearce et al. 1984).

tufos suportados por matriz cinerítica, tufos suportados por cristais e tufos estratificados, às vezes com evidên- cias de processos de milonitização ou metamorfismo. Apresentam-se afetados por metamorfismo/deforma- 


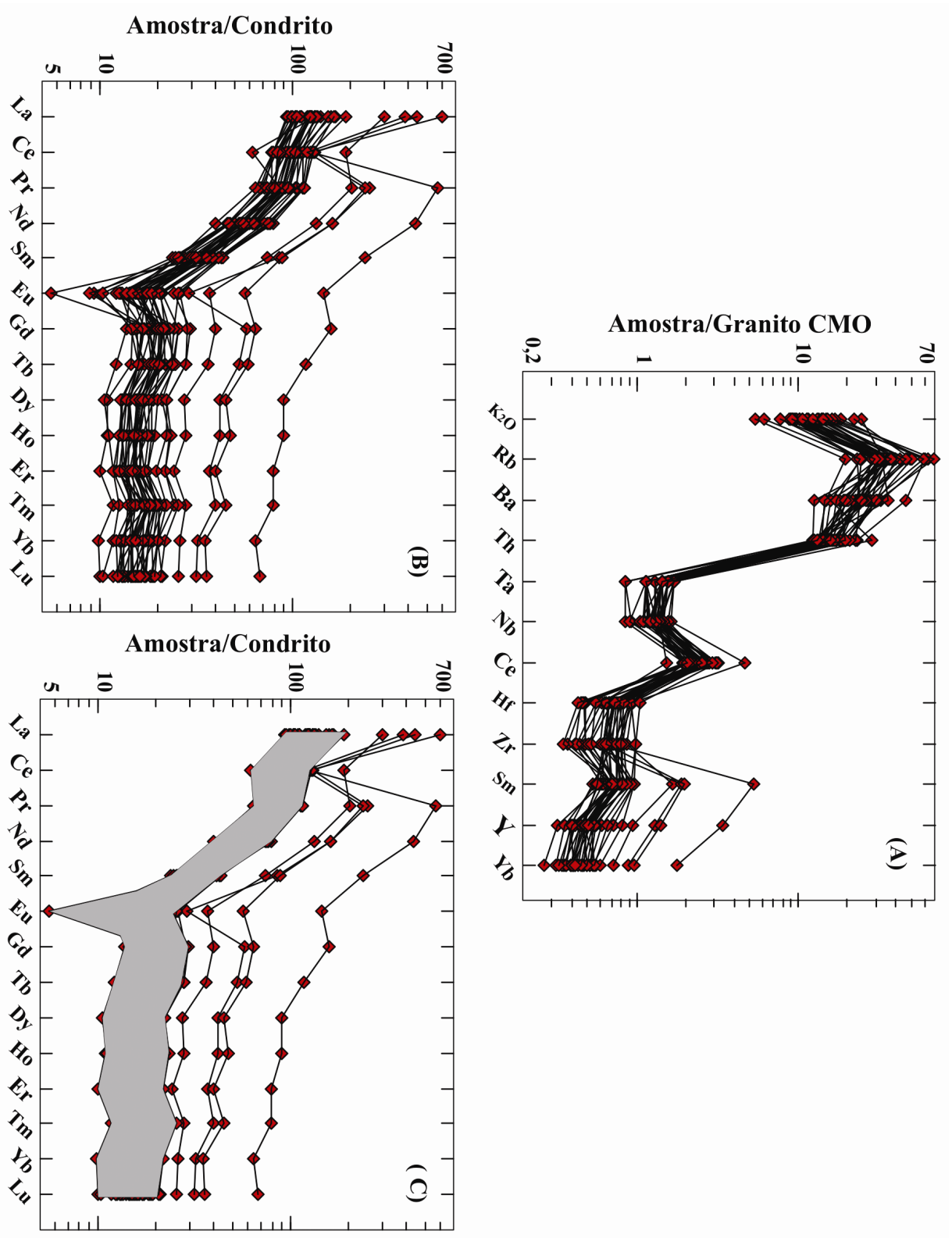

Figura 11 - Representação dos vulcanitos ácidos da PITP em diagramas: (A) Multielementares e K2O, normalizados pelos valores propostos por Pearce et al. (1984) para granitos de CMO; (B) de ETR, normalizados pelos valores condríticos de Nakamura (1977); (C) ilustrando o envelope representativo das amostras menos afetadas por processos posteriores à cristalização.

ção e hidrotermalismo regional de baixa temperatura, caracterizado por uma paragênese à base de sericita \pm epidoto \pm clorita \pm argilo-minerais \pm carbonato.

A matriz cinerítica fina pode ter se formado a partir de acumulação de material vitroclástico ou da elutriação das partículas menores dos depósitos coignimbrito. A elevada concentração de cristaloclastos encontrada na maioria das rochas indica uma origem a partir de magmas com alta taxa de cristalização, sendo que a intensa fragmentação neles identificada sugere impacto ao longo do conduto magmático ou transporte superficial turbulento.

Os embaiamentos e golfos de corrosão comu- mente identificados nos cristaloclastos devem ter sido formados durante a ascensão e extravasamento do magma quando, segundo McPhie et al. (1993), a solubilidade da $\mathrm{SiO} 2$ aumenta com a diminuição da pressão, e em conseqüência os fenocristais de quartzo que estão inicialmente em equilíbrio no líquido são parcialmente reabsorvidos. A presença de texturas esferulíticas denota processos de devitrificação. Segundo Lofgren (1971a) os esferulitos formados a altas temperaturas $\left( \pm 700^{\circ} \mathrm{C}\right)$ consistem de conjuntos abertos de cristais fibrosos bem espaçados; os feixes de fibras do tipo gravata borboleta caracterizam temperaturas intermediárias $\left(400-650^{\circ} \mathrm{C}\right)$, enquanto que os esféricos, os mais comumente obser- 
vados nas rochas da PITP, compreendem pacotes de fibras radiadas e caracterizam as mais baixas temperaturas $\left(<400^{\circ} \mathrm{C}\right)$. A textura micropoiquilítica composta de cristais finos de quartzo e feldspato, identificada com freqüência, se desenvolveu possivelmente através de devitrificação primária de material ácido, a altas temperaturas, em vidros que têm elevado conteúdo de água ou que são resfriados (ou reaquecidos) de maneira lenta (Lofgren 1971b). A presença de epidoto magmático evidencia a sua formação a partir da reação de líquidos de composição granítica com hornblenda, em pressões moderadas a altas, sob médias $\mathrm{fO}_{2}$ (Zen \& Hammarstron 1984), com concentrações de água próximas da saturação (Rivera et al. 2004). Quando encontrado em rochas formadas em níveis crustais rasos, tais como vulcânicas, Brandon et al. (1996) sugerem, a partir de medidas experimentais de dissolução de epidoto, que o transporte desse magma da crosta profunda se deu rapidamente para impedir sua reabsorção.

Geoquimicamente, as rochas estudadas constituem uma seqüência representada essencialmente por termos ácidos, com relativa homogeneidade composi- cional, variando de dacitos a riolitos, cujo comportamento independe do tipo faciológico. Esses litotipos foram formados a partir de um magma subalcalino, cálcio-alcalino do tipo I, que evoluiu de metaluminoso a peraluminoso, com moderada $\mathrm{fO}_{2}$. As anomalias negativas de $\mathrm{Eu}$ e de $\mathrm{Ce}$ observadas indicam, respectivamente, fracionamento de plagioclásio e alteração hidrotermal com provável interação com água do mar.

Todas essas considerações associadas à idade em torno de 1,76 Ga definida por Batata et al. (2005), sugerem uma correlação das rochas estudadas com a unidade estratigráfica Grupo Roosevelt (Lacerda Filho et al. 2004).

Agradecimentos A todos os professores, alunos e funcionários da UFMT, que de alguma maneira colaboraram para este trabalho. A investigação foi realizada com apoio de projeto de pesquisa $n^{\circ}$. 473117/03-7 do Conselho Nacional de Desenvolvimento Científico e Tecnológico - CNPq - Brasil, coordenado pelo Prof. Dr. Jayme Alfredo Dexheimer Leite.

\section{Referências}

Barrett T. J. \& MacLean W. H. 1999. Volcanic Sequences, Lithogeochemistry, and Hidrothermal Alteration in Some Bimodal Volcanic-Associated Massive Sulfide Systems. Reviews in Economic Geology, 8:101-131.

Basei M.A.S. 1977. Idade do vulcanismo ácido a intermediário na região amazônica. Dissertação de Mestrado, Instituto de Geociências, Univ. de São Paulo, 133 p.

Batata M.E.F., Menezes T., Leite J.A.D., Sousa M.Z.A., Nalon P.A., Comelli C., Santos A.A.S. 2005. Contribuição ao Conhecimento Geológico, Estrutural e Geocronológico das Rochas da Região de Filadélfia. In: Simpósio de Geologia do Centro-Oeste, 9, Goiânia-GO, Atas, p.200202.

Batata M.E.F. 2007. Vulcanitos Ácidos da Província Ígnea Teles Pires - SW do Cráton Amazônico na Região Médio Noroeste de Mato Grosso - Arcabouço e Estudo Petrológico. Dissertação de Mestrado, Instituto de Ciências Exatas e da Terra, Univ. Federal de Mato Grosso, 39p.

Brandon A.D., Creaser R.A, Chacko T. 1996. Constraints on Rates of Granitic Magma Transport from Epidote Dissolution Kinetics. Science 5257(271):1845-1848.

Cas R.A.F. \& Wright J.V.1987. Volcanic Successions - modern and ancient: a geological approach to processes, products and successions. 1 ed., London, Allen \& Unwin, 528 p.

Irvine T.N. \& Baragar W.R.A. 1971. A guide to the chemical classification of the common volcanic rocks. Can. $J$. Earth Sci., 8:523-548.

Lacerda Filho J.V., Souza J.O., Oliveira C.C., Ribeiro P.S.E., Boas P.F.V., Albuquerque M.C., Frasca A.A.S., Borges F.R., Moreton L.C., Martins E.G., Camargo M.A., Valente C.R., Pimentel M.M., Botelho N.F. 2001. Geologia e evolução tectônica da região norte do Mato Grosso
(Projeto Promin-Alta Floresta). In: SBG, Simp. Geol. Amazônia, 7, Belém, Anais (Sessão Temát. VII), CD Rom.

Lacerda Filho J.V., Abreu Filho W., Valente C.R., Oliveira C.C., Albuquerque M.C. 2004. Geologia e recursos minerais do estado de Mato Grosso. Programa integração, atualização e difusão de dados da geologia. CPRM, 200 p. e Mapas.

La Roche H. de, Leterrier J., GrandClaude P., Marchal M. 1980. A classification of volcanic and plutonic rocks using R1-R2 diagram and major-element analyses. Its relationships with current nomenclature. Chem. Geol., 29(2):183-210.

Le Maitre R.W. 2002. Igneous Rocks: a Classification and Glossary of Terms: Recommendations of the International Union of Geological Sciences Subcommission on the Systematics of Igneous Rocks. Cambridge, Cambridge University Press, 236 p.

Leite J.A.D. \& Saes G.S. 2000. Geology of southern Amazon Cráton, in southwestern Mato Grosso, Brazil: a review. Rev. Bras. Geoc., 30(1):91-94.

Leite J.A.D., Saes G.S., Macambira M.J.B. 2001a. The Teles Pires volcanic province: a Paleoproterozoic silic-dominated large igneous province in southwest Amazon Craton and tectonic implications. In: Sociedad Geologica de Chile, Simpósio Sulamericano de Geologia Isotópica, 3, Pucón Chile, Anais, vol. 1, p.180-183.

Leite J.A.D., Saes G.S., Macambira M.J.B. 2001b. The southwest portion of Amazon Craton in Mato Grosso, Brazil: The state-of-art of geologic knowledge. In: Workshop on the Geology of SW Amazonic Craton, 1, Ed. IG-USP, $64 \mathrm{p}$.

Leite J.A.D \& Saes G.S. 2003. Geocronologia $\mathrm{Pb} / \mathrm{Pb}$ de zircões detríticos e análise estratigráfica das coberturas se- 
dimentares proterozóicas do sudoeste do Cráton Amazônico. Revista do Instituto de Geociências da USP, Série Cientifica, 3:113-127.

Leite J.A.D., Sousa M.Z.A, Saes G.S., Macambira M.J.B., Xavier R.P., Siqueira A.J., Batata M.E.F., Oliveira F.A., Silva Jr J.G., Quadros A.P. 2005. Caracterização do Depósito Polimetálico ( $\mathrm{Zn}, \mathrm{Pb}, \mathrm{Ag}, \mathrm{Cu}-\mathrm{Au})$ de Aripuanã, Mato Grosso. In: Marini O.J., Queiroz E.T., Ramos W.B. (ed.) Caracterização de Depósitos Minerais em Distritos Mineiros da Amazônia. Brasília, DNPM-CT-Mineral/ FINEP-ADIMB, p. 601 a 686.

Leite J.A.D., Souza M.Z.A., Saes G.S., Batata M.E.F., Oliveira F.A., Menezes T., Freitas F.A.O., Gomes M.F., Uchôa J., Silva V.F., Silva D.R. 2006. Geologia, geocronologia e evolução crustal de partes da porção sul do Cráton Amazônico no Alto Estrutural Eugênia-Arinos, médio-noroeste de Mato Grosso. In: Viana R.R. \& Fernandes C.J. (Org.) Coletâneas Geológicas do estado de Mato Grosso: Geologia Regional. $1^{\mathrm{a}}$ ed., EDUFMTLenice, vol. 1, p. 61-76.

Liaghat S. \& MacLean W.H. 1995. Lithogeochemistry of altered rocks at the New Insco VMS deposit, Noranda, Quebec. Journal Geochem. Explor., 52:333-350.

Lofgren G. 1971b. Experimentally produced devitrification textures in natural rhyolite glass. Geological Society of America Bulletin, 82:111-123.

Lofgren G. 1971a. Spherulitic textures in glassy and crystalline rocks. Journal of Geophysical Research, 76(23):5635-5648.

Maniar P. D. \& Piccoli P.M. 1989. Tectonic discrimination of granitoids. Geol. Soc. Amer. Bull., 101:635-643.

McPhie J., Doyle M., Allen R. 1993. Volcanic Textures. A guide to the interpretation of textures in volcanic rocks. Tasmania, Tasmanian Gov. Printing Office, 198p.

Munhá J. \& Kerrich R.1980. Seawater - basalt interaction from the Iberian Pyrite Belt. Contrib. Mineral. and Petrol., 73:191-200.

Nakamura K. 1977. Volcanoes as a possible indicator of tectonic stress orientation: principle and proposal. J. Volcanol. Geotherm. Res., 2:1-16.

Néder R.D.N., Figueiredo B.R., Beaudry C., Collins C., Leite J.A.D. 2000. The Expedito Massive Sulphide Deposit, Mato Grosso. Rev. Bras. Geoc. 30(2):222-225.

Néder R.D., Figueiredo B.R., Tassinari C.C.G., Leite J.A.D. 2001. Implicações genéticas da alteração cálcio-silicática do depósito de $\mathrm{Zn}-\mathrm{Pb}$ da Serra do Expedito, Aripuanã, MT. In: Bettencourt J. S., Teixeira W., Pacca I. G., Geraldes M. C., SparrenbergerI. (eds.). Geology of SW Amazon Craton: the state-of-art. IG-USP, 1:130-135.

Peacock M.A. 1931. Classification of igneous rock series. Journal of Geology, 39:54-67.

Pearce J.A., Harris N.B.W., Tindle A.G. 1984. Trace element discrimination diagrams for the tectonic interpretation of granitic rocks. J. Petrol., 25(4):956-983.

Pearce J.A. 1996. Sources and settings of granitic rocks. Episodes, 19:120-125.

Pinho M.A.S.B., Schmus W.R.V., Chemale Jr. F., Pinho F.E.C. 2003. U-Pb and Sm-Nd evidence for $1.78 \mathrm{Ga}$ magmatism in the Moriru Region, Mato Grosso, Brasil: implications for province boundaries in the Amazon Craton. Precam- brian Research, 126(1):1-25.

Rizzotto G.J., Quadros M.L.E.S., Silva L.C., Armstrong R., Almeida M. 2002. O Granito Aripuanã: datação U-Pb (SHRIMP) e implicações metalogenéticas. In: SBG, Congresso Brasileiro de Geologia, 41, João Pessoa. Anais, p. 469.

Rivera C.B., Bitencourt M.F., Nardi L.V.S. 2004. Integração de parâmetros físicos do magma e composição química dos minerais na petrogênese do Granito Itapema, SC. Revista Brasileira de Geociências, 34(3):361-372.

Rollinson H.R.1993. Using Geochemical Data: Evaluation, Presentation, Interpretation. $1^{\text {a }}$ ed., Singapore, Pearson Education Asia (Pte) Ltd., 352p.

Santos J.O.S., Hartmann L.A., Gaudette H.E., Groves D.I., McNaughton N.J., Fletcher I.R.A. 2000. New understanding of the provinces of the Amazon Craton based on integration of field mapping and $\mathrm{U}-\mathrm{Pb}$ and $\mathrm{Sm}-\mathrm{Nd}$ geochronology. Gondwana Research, 3(4):453-488.

Santos J.O.S., Groves D., Hartmann L.A., Moura M.A., McNaughton N.J. 2001. Gold deposits of the Tapajós and Alta Floresta domains, Tapajós-Parima orogenic belt, Amazonian Craton, Brazil. Mineralium Deposita, 36:278-299.

Scheepers R. 1995. Geology, geochemistry and petrogenesis of Late Precambrian S-, I- and A- type granitoids in the Saldania belt, Western Cape Province, South Africa. Journal of African Earth Sciences, 21(1):35-58.

Sparks R.S.J. \& Walker G.P.L. 1973. Products of ignimbrite eruptions. Geology (Boulder), 1(3):115-118.

Sylvester P.J. 1989. Post-Collisional Alkaline Granites. Journal of Geology, 97:261-280.

Tassinari C.C.G., Siga Jr. O., Teixeira W. 1984. Épocas metalogenéticas relacionadas à granitogênese do Cráton Amazônico, In: SBG, Cong. Bras. Geol., 32, Anais, vol. 6, p. 2963-2977.

Tassinari C.C.G., Cordani U.G., Nutman A.P., Van Schmus W.R., Bettencourt J.S., Taylor P.N. 1996. Geochronological systematics on basement rocks from the Rio NegroJuruena Province (Amazonian Craton), and tectonic implications. Intern. Geology Review, 38(2):161-175.

Tassinari C.C.G. \& Macambira M.J.B. 2000. Geochronological Provinces of the Amazonian Craton. Episodes, 22(3):174-182.

Whalen J.B., Currie K.L., Chappell B.W. 1987. A-Type Granites - Geochemical Characteristics, Discrimination and Petrogenesis. Contributions to Mineralogy and Petrology, 95(4):407-419.

Williams H. \& McBirney A.R. 1979. Volcanology. San Francisco, Freeman, Cooper and Company, 397 p.

Winchester J.A. \& Floyd P.A. 1977. Geochemical discrimination of different magma series and their differentiation products using immobile elements. Chem. Geol., 20:325-343.

Zen E.A. \& Hammarstrom J. 1984. Magmatic epidote and its petrologic significance. Geology, 12(9):515-518.

Manuscrito AE 088/2006

Submetido em 23 de maio de 2007 Aceito em 03 de junho de 2008 